\title{
FROM JEW TO PURITAN: THE EMBLEMATIC OWL IN EARLY ENGLISH CULTURE
}

\author{
Brett D. Hirsch
}

Puritan in Northamptonshire takes offence to his neighbour's maypole and
threatens to have it taken down, despite the anticipated costs of litigation.
His neighbour is understandably taken aback by this confrontation, and after questioning the Puritan's authority in the matter, takes his leave and returns to his home. He emerges soon after with an owl on his arm. Turning to the Puritan, he asks him to identify the bird he is holding: 'An owl,' is the response. 'No,' says the man, 'tis a Roundhead on my fist, I hope I may call my Bird what I list.' The Puritan, fuming at this insult, brings his case before a Justice, who recognizes a man's right to name his pets and dismisses the claim.

This is the plot of My Bird is a Round-head, a broadside ballad printed in 1642, the infamous year in which the Puritan parliament succeeded in closing down the London theatres. ${ }^{1}$ The ballad, which features a custom woodcut depicting the man holding his owl next to the offending maypole (Figure 6), juxtaposes one Roundhead against another: a Roundhead in the political sense (so named because of the distinctive haircut worn by the Puritan faction of parliament), and an owl, the only bird with its eyes on the front of its (round) face. The feathered Roundhead is shown to be 'a gallant Bird' (13. 5) that, unlike its Puritan namesake, 'hurteth none' (8.5) and

meddles not with State affaires,

Or sets her neighbours by the eares,

I wish to thank Anne and Chris Wortham, Gabriel Egan, David Scott Kastan, and Bruce Boehrer for their insightful comments and suggestions.

${ }^{1}$ Humphrey Crouch, My Bird is a Round-head (London, 1642; Wing C7285B). Stanza and line references are given parenthetically in the text. 


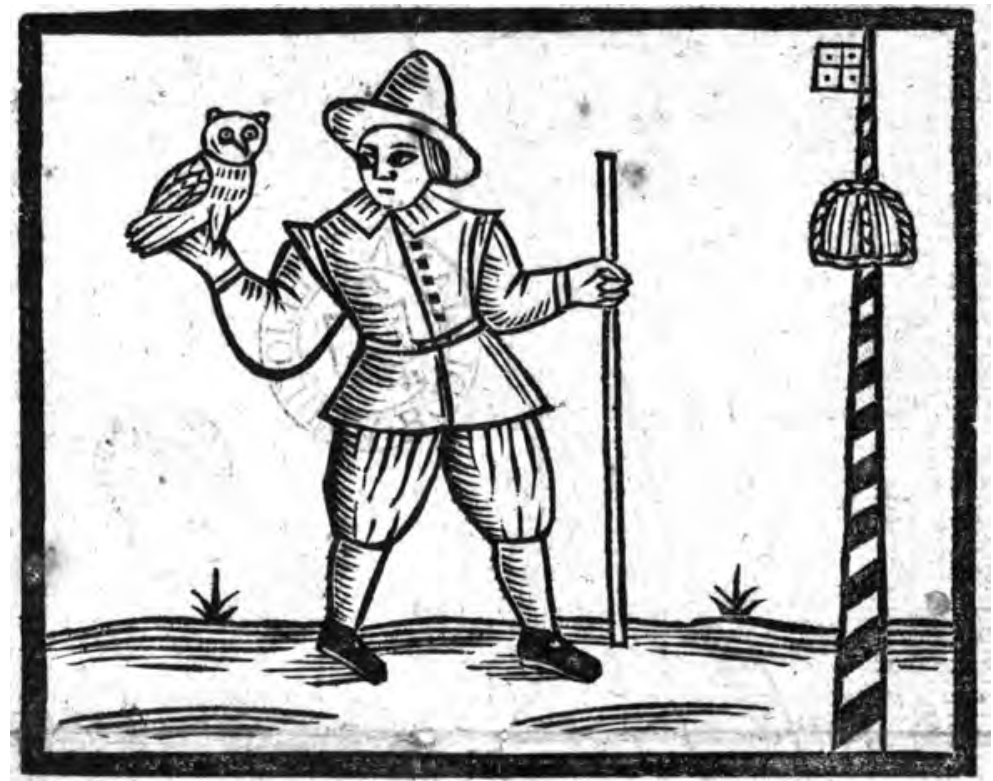

Figure 6. Woodcut of a man with an owl by a Maypole. Humphrey Crouch, My Bird is a Round-head (London, 1642). Oxford, Bodleian Library, MS Ashmolean H 23. By permission of the Bodleian Library, University of Oxford.

No Crosse or May-pole makes her start,

Nor can she preach in Cup or Cart;

She seekes to pull no Organs downe,

Nor on an Image casts a frowne. (9.1-6)

Published during the early days of the Civil War, this ballad pointedly ridicules religious extremists like the Puritan who 'with meere toyes doe trouble [their] pates' (1.6), fussing over such trifles as maypoles and pet owls with amusing names. ${ }^{2}$

Sectarian humour aside, the ballad is of interest because of its use of the owl a bird routinely identified with Jews in early English culture - to symbolically represent Puritans. This chapter will explore the transmission of medieval antisemitic textual and visual narratives into early modern England, focusing on the ways in which the emblem of the owl was appropriated in charging Catholics with

${ }^{2}$ I am indebted to the pseudonymous Hieronimo of Blogging the Renaissance for bringing this wonderful ballad to my attention: 'An Odd Ballad: "My Bird is a Round-head", <http:// www.bloggingtherenaissance.blogspot.com/2006/04/odd-ballad-my-bird-is-round-head.html> [accessed 25 June 2006]. 
judaizing during the various Reformations, through to its later adaptation as part of the stigmatization of Puritans as Jews in the seventeenth century. ${ }^{3}$

\section{The Jews in Medieval England and their Cultural Legacy}

Scholarly consensus is that Jews migrated to England in substantial numbers only after the Norman Conquest in the late eleventh century, ${ }^{4}$ although it has been suggested that there is evidence of their presence as early as the Roman period. ${ }^{5}$ In many ways, the experience of medieval English Jewry was no different from that of their brethren in other parts of Christendom: theirs was a life dogged by State- and Church-sponsored sanctions, suspicion and hostility, and social and economic restrictions designed to humiliate and alienate, culminating in their wholesale expulsion in 1290.

However, England was also to herald a number of firsts in the history of Christian-Jewish relations. England was the first country in Europe to vigorously enforce the wearing of the Jew Badge only three years after the Fourth Lateran Council had instituted it in 1215:

Whereas in certain provinces of the Church the difference in their clothes sets the Jews and Saracens apart from the Christians, in certain other lands there has arisen such confusion that no differences are noticeable. Thus it sometimes happens that by mistake Christians have intercourse with Jewish or Saracen women, and Jews or Saracens with Christian women. Therefore, lest these people, under the cover of an error, find an excuse for the grave sin of such intercourse, we decree that these people (Jews and Saracens) of either sex, and in all Christian lands, and at all times, shall easily be distinguishable from

${ }^{3}$ This chapter follows Anthony Bale in preferring antisemitism to anti-Judaism, since the narratives under consideration here do not refer to 'real' Jews but 'only deprecatory non-Jewish ideas about Jews', as opposed to narratives that aim to attack real Jews or the Jewish religion on a practical level. Likewise, the term has not been hyphenated since 'outside linguistics, there is no such thing as a Semite; it is only a negative category forced onto Jews, and others': Anthony Bale, The Jew in the Medieval Book: English Antisemitisms, 1350-1500 (Cambridge: Cambridge University Press, 2007), p. 3.

${ }^{4}$ Representative studies include Andrew P. Scheil, The Footsteps of Israel: Understanding Jews in Anglo-Saxon England (Ann Arbor: University of Michigan Press, 2004); Cecil Roth, A History of the Jew in England, 3rd edn (Oxford: Clarendon Press, 1964); Albert M. Hyamson, A History of the Jew in England (London: Chatto \& Windus, 1908); and Joseph Jacobs, The Jews of Angevin England (London: David Nutt, 1893).

5 Shimon Applebaum, 'Were There Jews in Roman Britain?', Transactions of the Jewish Historical Society of England, 17 (1951-52), 189-205. 
the rest of the population by the quality of their clothes; especially since such legislation is imposed upon them also by Moses. ${ }^{6}$

Literary scholars have long recognized possible echoes of this legislation in Shakespeare's Merchant of Venice, where Shylock refers to his 'Iewish gaberdine' (440, I. 3. 111), or even, more loosely, to 'the badge of all [his] Tribe' (438, I. 3. 109).? Whether such readings are persuasive or not, it is interesting to note that the requirement of wearing the badge - and later the pileum cornutum, the pointed or horned Jewish hat prescribed by the Council of Vienna in 1267 — was 'enforced earlier and more consistently in England than in any other country of Europe, ${ }^{8}$ a fact that has led Janet Adelman to insightfully reflect that

\begin{abstract}
By the time of Merchant, Christian societies had been worrying about the instability of Jewish difference for generations. Jews, for example, are generally depicted throughout the Middle Ages as physically un mistakable, with red or black curly hair, large noses, dark skin, and the infamous foetor judaicus, the bad smell that identified them as Jews. But apparently Jews could not be counted on to be reliably different: although allegedly physically unmistakable, Jews throughout Europe were nonetheless required to wear particular styles of clothing or badges that graphically enforced their physical unmistakability — as though they were not quite different enough. ${ }^{\text {? }}$
\end{abstract}

Jewish opposition was not only figured in physiological terms, but found concrete physical expression in the widely circulated narratives detailing the Jewish desecration of the Eucharistic Host, ${ }^{10}$ the murder of Christian children in mockery of the Passion, and the use of Christian blood for ritual purposes. The first documented case of the charge of Ritual Murder is that of William of Norwich in 1144,

${ }^{6}$ As reprinted in Steven F. Kruger, 'Conversion and Medieval Sexual, Religious, and Racial Categories', in Constructing Medieval Sexuality, ed. by Karma Lochrie, Peggy McCracken, and James A. Schultz (Minneapolis: University of Minnesota Press, 1997), pp. 158-79 (p. 168).

${ }^{7}$ All references to Shakespeare are taken from the First Folio of 1623, and are cited parenthetically throughout as Through Line Numbers from the Norton Facsimile, 2nd edn (New York: Norton, 1996), ed. by Charles Hinman, followed by corresponding act, scene, and line references from William Shakespeare, Complete Works, ed. by Stanley Wells and Gary Taylor (Oxford: Oxford University Press, 1986).

${ }^{8}$ Roth, History of the Jews in England, p. 95.

9 Janet Adelman, 'Her Father's Blood: Race, Conversion, and Nation in The Merchant of Venice', Representations, 81 (2003), 4-30 (p. 10, emphasis original).

${ }^{10}$ For a thorough examination of the Host-desecration narrative, see Miri Rubin, Gentile Tales: The Narrative Assault on Late Medieval Jews (New Haven: Yale University Press, 1999). 
over a quarter of a century before the charges are recorded on the Continent. ${ }^{11}$ Further allegations are recorded in Gloucester (1168), Bury St Edmunds (1181), Bristol (1183), Winchester (1191), London (1244), and, most famously, in Lincoln (1255). ${ }^{12}$ The story of Little St Hugh of Lincoln served as Chaucer's source for the Prioress's Tale and has attracted much scholarly attention. ${ }^{13}$ The boy's remains were interred in a shrine in Lincoln Cathedral, 'where the relics were venerated down to the time of the Reformation', and his story inspired popular ballads and entered the cultural memory of England. ${ }^{14}$ It is clear that readers in early modern England were aware of these stories, since they are to be found in popular martyrologies and chronicles. For example, both William of Norwich and Little St Hugh of Lincoln are reported in John Foxe's Acts and Monuments and

${ }^{11}$ Roth, History of the Jews in England, pp. 9-11. For a more detailed discussion of the ritualmurder accusation, see the useful collection of essays in The Blood Libel Legend: A Casebook in Anti-Semitic Folklore, ed. by Alan Dundes (Madison: University of W isconsin Press, 1991). Other important studies include R. Po-chia Hsia, The Myth of Ritual Murder: Jews and Magic in Reformation Germany (New Haven: Yale University Press, 1988); and Joshua Trachtenberg, The Devil and the Jews: The Medieval Conception of the Jew and its Relation to Modern Antisemitism (Philadelphia: Jewish Publication Society, 1984). On William of Norwich, see Gavin I. Langmuir, 'Thomas of Monmouth: Detector of Ritual Murder', Speculum, 59 (1984), 820-46; and John M. McCulloh, 'Jewish Ritual Murder: William of Norwich, Thomas of Monmouth, and the Early Dissemination of the Myth', Speculum, 72 (1997), 698-740.

${ }^{12}$ For a more detailed discussion of these cases, see Anthony Bale, 'Fictions of Judaism in England before 1290', in The Jews in Medieval Britain: Historical, Literary and Archaeological Perspectives, ed. by Patricia Skinner (Woodbridge: Boydell, 2003), pp. 129-44; and Joe Hillaby, 'The Ritual Child Murder Accusation: Its Dissemination and Harold of Gloucester', Jewish Historical Studies, 34 (1994-96), 69-106.

${ }^{13}$ Representative recent studies include Catherine S. Cox, The Judaic Other in Dante, the Gawain Poet, and Chaucer (Gainesville: University Press of Florida, 2005); Roger Dahood, 'The Punishment of the Jews, Hugh of Lincoln, and the Question of Satire in Chaucer's Prioress's Tale, Viator, 36 (2005), 465-91; Lisa Lampert, Gender and Jewish Difference from Paul to Shakespeare (Philadelphia: University of Pennsylvania Press, 2004), chap. 3; Sheila Delany, 'Chaucer's Prioress, the Jews, and the Muslims', Medieval Encounters, 5 (1999), 198-213; and Denise L. Depres, 'Cultic Anti-Judaism and Chaucer's Litel Clergeon', Modern Philology, 91 (1994), 413-27. For a more detailed discussion of Little St Hugh of Lincoln, see Gavin I. Langmuir, 'The Knight's Tale of Young Hugh of Lincoln', Speculum, 47 (1972), 459-82. There have been studies of the other child martyrs - in particular Robert of Bury, who is referred to in a poem by Lydgate - but they have not received the same level of scholarly attention. These studies include Bale, The Jew in the Medieval Book, chap. 4; and Lisa Lampert, 'The Once and Future Jew: The Croxton Play of the Sacrament, Little Robert of Bury and Historical Memory', Jewish History, 15 (2001), 235-55.

${ }^{14}$ Roth, History of the Jews in England, pp. 56-57. 
John Wilson's The English Martyrologe, as well as in the collaborative Epitome of Chronicles and Raphael Holinshed's Chronicles, ${ }^{15}$ with other accounts found in works by John Merbecke, John Stow, John Donne, and John Weever. ${ }^{16}$ Roy Booth has provocatively suggested that the shadow of these child martyrs lingers over the immediate reception of Shakespeare's Merchant of Venice, arguing that Nerissa's safe return from the Jew's house (disguised as a boy clerk) indicates 'in an undemonstrative way that Shylock's threat has been completely nullified. ${ }^{17}$ Booth also argues persuasively, by close examination of contemporary ballads and an episode in Thomas Nashe's Unfortunate Traveller, for the existence of a 'lurid fiction' and 'pattern' that perceives 'the Jew's house as a trap for Christians'. ${ }^{18}$ It is entirely plausible that Shakespeare's original audiences may have expected something more sinister from this off-stage encounter with Shylock.

Later versions of these allegations took on an additional element of cruelty and depravity, combining the traditional charge of ritual murder with what has come to be known as the Blood Libel - the accusation that the Jews required Christian blood for ritual purposes. ${ }^{19}$ Beginning on the Continent, the blood libel soon reached England and tainted the memory of the child martyrs, and was added to the corpus of charges laid against the Jews. For example, as part of his sermon on Christmas Day, 1625, John Donne argued that the truth of Christianity was so convincing that even the Jews

${ }^{15}$ John Foxe, Actes and Monuments (London, 1570; STC 11223), $4^{\mathrm{r}}, \mathrm{N} 1^{\mathrm{v}}$; John W ilson, The English Martyrologe (London, 1608; STC 25771), E7 ${ }^{\mathrm{v}}-\mathrm{E}^{\mathrm{r}}, \mathrm{N}^{\mathrm{v}}-\mathrm{N} 7^{\mathrm{r}}$; Thomas Lanquet, Thomas Cooper, and Robert Crowley, An Epitome of Chronicles (London, 1559; STC 15217.5), 3F $4^{\mathrm{r}}, 3 \mathrm{G}^{\mathrm{v}}$, $3 \mathrm{H}^{\mathrm{r}}, 3 \mathrm{I} 4^{\mathrm{r}}$; Raphael Holinshed, The Third Volume of Chronicles (London, 1587; STC 13569), p. 56, p. 219.

${ }^{16}$ John Merbecke, A Booke of Notes and Common Places (London, 1581; STC 17299), 2L6 ${ }^{\text {r-v }}$; John Stow, A Suruay of London (London, 1598; STC 23341), C8 $8^{\mathrm{r}}$; John Donne, Pseudo-Martyr (London, 1610; STC 7048), 2K1 ${ }^{\mathrm{r}}$; John Weever, Ancient Funerall Monuments (London, 1631; STC 25223), $2 \mathrm{~K}^{\mathrm{r}}$.

${ }^{17}$ Roy Booth, 'Shylock's Sober House', Review of English Studies, 50 (1999), 22-31 (p. 23).

${ }^{18}$ Booth, 'Shylock's Sober House', pp. 26-27.

${ }^{19} \mathrm{On}$ the blood libel in general, see the already cited collection of essays in The Blood Libel Legend, ed. by Dundes. Other important studies include Hsia, The Myth of Ritual Murder; and Trachtenberg, The Devil and the Jews, pp. 140-58; Cecil Roth. 'The Feast of Purim and the Origins of the Blood Accusation', Speculum, 8 (1933), 520-26; and Hermann L. Strack, The Jew and Human Sacrifice: An Historical and Sociological Inquiry, trans. by Henry Blanchamp (London: Cope \& Fenwick, 1909). 
express a kinde of conditionall acknowledgement of it, by this barbarous and inhumane custome of theirs, that they alwayes keep in readinesse the blood of some Christian, with which they anoint the body of any that dyes amongst them, with these words, if Jesus were the Messias, then may the blood of this Christian availe thee to salvation. ${ }^{20}$

For Donne, 'so by their doubt, and their implyed consent', ${ }^{21}$ the ritual use of Christian blood becomes proof that the Jews secretly acknowledge Christ as the Messiah - or, at least, that they are willing to hedge their bets.

Another important development to emerge in England was the iconographic representation of Moses with horns. In her monumental study, The Horned Moses in Medieval Art and Thought, Ruth Mellinkoff finds that 'the earliest artistic representation thus far found of horns on Moses is in eleventh-century England', ${ }^{2}$ pointing to a number of manuscript illuminations and sculptures, such as the statue of Moses from St Mary's Abbey in York. Although more famous works existed on the Continent, such as Michelangelo's sculpture in the Church of San Pietro in Vincoli in Rome, the catalogue of examples collected by Mellinkoff indicates that the motif was quite popular in medieval England.

Why was Moses depicted with horns? The phenomenon stands as one of the great moments of being lost in translation. Henry Ainsworth, glossing Exodus 34. 29, explained that

The Latine version [the Vulgate] saith, Moses face was horned; mistaking the word: for the Hebrew Karan, which is to shine, or cast forth glorious beames, the name Keren or Horne is derived: in which sense the Latine translated it here, and gave occasion to the ignorant, to paint Moses face with two hornes like an Oxe, whereby this glorious mystery hath been obscured, and turned to a fable. ${ }^{23}$

It is only after the production of the Geneva Bible in 1560 that references to Moses' horns were purged from this passage. ${ }^{24}$ Other post-Reformation authors in England were quick to assign this error to the Catholics: John Boys wrote that 'the

${ }^{20}$ John Donne, LXXX Sermons (London, 1640; STC 7038), p. 21.

${ }^{21}$ Donne, LXXX Sermons, p. 21.

${ }^{22}$ Ruth Mellinkoff, The Horned Moses in Medieval Art and Thought (Berkeley: University of California Press, 1970), p. 13.

${ }^{23}$ Henry Ainsworth, Annotations Upon the Five Bookes of Moses (London, 1627; STC 219), $2 \mathrm{M} 6^{\mathrm{v}}$.

${ }^{24}$ James Strachan, Early Bible Illustrations (Cambridge: Cambridge University Press, 1957), p. 14. For example, the Great Bible of 1540 gives 'And Moses wyst not that the skynne of his face shone in maner of an horne, whyle he talked with him', while the Geneva Bible reads 'Moses wist not that the skinne of his face shone bright, after that God had talked with him'. 
common painters among the Papists' paint Moses with two horns 'as a cuckold, to the great scandall of Christian religon'. ${ }^{25}$ Andrew Willet, on the other hand, noted that as a result of this 'common errour [...] the Jewes deride the Christians', since in doing so they 'picture Moses with hornes, more like a Devill, than a man'. ${ }^{26}$ Willet's comment touches on another important association - that of the Devil and the Jews - one that was familiar in medieval and early modern Europe, and has been sufficiently discussed elsewhere. ${ }^{27}$ Indeed, the pointed or horned hat that Jews were forced to wear only reinforced this diabolic affiliation.

As these many examples indicate, medieval English attitudes towards the Jews found their expression in graphic and literary narratives, often developing new forms and motifs that would later become popular on the Continent. Even though the Jews were expelled in 1290, these narratives remained in cultural memory the Jewish presence was felt in England long before their de facto readmission under Cromwell in the 1650s.

\section{The Emblematic Owl}

Since antiquity, the symbol of the owl has embodied a variety of meanings. In classical antiquity the owl was associated with Pallas Athena/Minerva, and was therefore a symbol of wisdom and knowledge. The pair was a popular motif in the Renaissance as a result of the humanist project to rekindle the intellectual and aesthetic flames of classical antiquity - despite the claim by Marija Gimbutas that the Renaissance knew only a single classical representation of Athena/Minerva and her owl. ${ }^{28}$ While Athena/Minerva is often depicted without her feathered companion in Renaissance art, the pair appeared in emblem books, ${ }^{29}$ and numerous

\section{$2 \mathrm{G} 3^{\mathrm{v}}$.}

${ }^{25}$ John Boys, An Exposition of the Dominical Epistles and Gospels (London, 1610; STC 3458),

${ }^{26}$ Andrew Willet, Hexapla in Genesin \& Exodum (London, 1633; STC 25685), 3N2r.

${ }^{27}$ For a more detailed discussion of the association between the Devil and the Jews, see Debra Higgs Strickland, Saracens, Demons, and Jews: Making Monsters in Medieval Art (Princeton: Princeton University Press, 2003), pp. 95-155; and Trachtenberg, The Devil and the Jews, pp. $11-53$.

${ }^{28}$ Marija Gimbutas, The Language of the Goddess (London: Thames and Hudson, 1989), pp. 190-95. For a discussion of classical motifs in Renaissance art, see Malcolm Bull, The Mirror of the Gods: How the Renaissance Rediscovered the Pagan Gods (New York: Oxford University Press, 2005).

${ }^{29}$ For example, Andrea Alciato, Emblemata (Leiden, 1591), emblem 17, 'Prudens magis quam loquax' (C2 ${ }^{\mathrm{v}}$ ); Guillaume de la Perrière, Morosophie (Lyon, 1553), emblems 18 (D6 ${ }^{\mathrm{v}}-\mathrm{D} 7^{\mathrm{r}}$ ), 49 
references are found in poems, ${ }^{30}$ plays,${ }^{31}$ and other printed matter in early modern England. ${ }^{32}$ That the owl represents wisdom, whether accompanied by Athena/ Minerva or not, is a commonplace that extends to our own time, and numerous examples can be found in early English literature. ${ }^{33}$

While the wise owl of classical antiquity was clearly absorbed into later cultures, so too were its more negative symbolic connotations. In medieval iconography, the owl's classical association with wisdom was literally turned on its head: the once wise owl came to represent folly and false wisdom, particularly in depictions of the

$\left(\mathrm{H} 5^{\mathrm{v}}-\mathrm{H} 6^{\mathrm{r}}\right), 90\left(\mathrm{~N}^{\mathrm{v}}-\mathrm{N} 7^{\mathrm{r}}\right)$, and $98\left(\mathrm{O}^{\mathrm{v}}-\mathrm{O} 7^{\mathrm{r}}\right)$; Joannes Sambucus, Emblemata (Antwerp, 1564), 'Persei fabula' (pp. 148-49) and 'Iudicium Paridis' (pp. 152-53); and George Wither, A Collection of Emblemes, Ancient and Moderne (London, 1635; STC 25900a-d), emblem 9 (C1 ${ }^{\mathrm{r}}$ ).

${ }^{30}$ In Samuel Daniel's poem, The Ciuile Wars Between the Howses of Lancaster and Yorke (London, 1609; STC 6245), a marginal gloss of 'Mineruas bird' (2.100.1) reads, 'The Owle is said to bee Mineruas bird' (p. 58). Sonnet XVII in Thomas Watson's Hekatompathia or Passionate Centurie of Loue (London, 1582; STC 25118a), asks 'why Venus likes the Doue; | Or why the Owle befitts Mineruaes grace' $\left(\mathrm{Cl}^{\mathrm{r}}\right)$.

${ }^{31}$ For example, Phineas Fletcher's pastoral drama, Sicelides (London, 1631; STC 11083), originally intended as an entertainment for King James during his visit to Cambridge in 1615, has the lustful old fisherman Fredocaldo announce that it is 'O wle-light, Mineruaes waggoner' $\left(\mathrm{H}_{2}{ }^{v}\right)$ at the beginning of Act IV, scene 4.

${ }^{32}$ Robert Greene in particular was fond of referring to Minerva's owl: see Morando the Tritameron of Loue (London, 1584; STC 12276), D 1"; Euphues his Censure to Philantus (London, 1587; STC 12239), L1 ${ }^{\mathrm{r}}$; and Greenes Farewell to Folly (London, 1591; STC 12241), C $1^{\mathrm{v}}$. Minerva's owl also appears in Peter Lowe's dedication to James VI in his medical treatise, The Whole Course of Chirurgerie (London, 1597; STC 16869.5), A2v'; Robert Kittowe's prose romance, Loues Load-Starre Liuely Deciphered (London, 1600; STC 15026), F2 ${ }^{\mathrm{v}}$; and John Selden's encyclopaedic Titles of Honor (London, 1614; STC 22177), p. 155 (Book 1, Chapter 7). Numerous and earlier examples are found on the Continent, such as the woodcut of Pallas with her owl in the first printed edition of Giovanni Boccaccio's De Claris Mulieribus (Ulm, 1473), $8^{\mathrm{v}}$.

${ }^{33}$ In the anonymous medieval debate-poem, The Owl and the Nightingale, the owl argues that she is wise because she guards herself with plain truth, while the verbose nightingale 'hauest to monie tale' and should give her tongue a rest (lines 255-64). The owl is also wise because she avoids quarreling with fools (like the nightingale) by staying in her nest during the day (lines 281-94). References to The Owl and the Nightingale are to The Owl and the Nightingale, ed. by J. H. G. Grattan and G. F. H. Sykes (London: Early English Text Society, 1935). Michael Drayton's The Owle (London, 1604; STC 7212), a 'general satire on man', identifies the owl as 'partly the voice of wisdom, partly that of Drayton himself fulfilling what he believed to be one of the sacred roles of the poet': Richard F. Hardin, Michael Drayton and the Passing of Elizabethan England (Lawrence: University Press of Kansas, 1973), pp. 78-79. 
figure of Nobody with his winged cap or an owl nesting on his head. ${ }^{34}$ The medieval interest in etymology also brought the bird's long-standing association with death and sorrow to new light. Although the terminology was often confused and conflated - particularly in bestiaries - medieval authors distinguished four types of owl, drawing on Pliny and ultimately Aristotle: the screech owl (ulula or strix), the horned owl (bubo), the night owl or little owl (noctua), and the night raven (nycticorax). According to Isidore of Seville, both the ulula and bubo are so named because their calls resemble weeping, wailing, and lamentation, ${ }^{35}$ and later authors would repeat this description. ${ }^{36}$

As a nocturnal bird with a haunting cry, often found in 'olde Sepulchres, and in Housen or Barnes not often frequented, and in cauernes or holes or stone walles' as in crypts and graveyards, ${ }^{37}$ perhaps it was inevitable that the owl would be perceived as an ill omen and harbinger of death. According to Book 5 of Ovid's Metamorphoses, Proserpine turned Ascalaphus into a 'skreching Owle' for 'blabbing ungraciously' that she had eaten pomegranate seeds, thus ensuring her return to Hades. ${ }^{38}$ The identification of the owl as 'a cursed Birde' and a 'messenger of $\mathrm{Mo}[\mathrm{u}] \mathrm{rning}$ ' (nuntia luctus) in Ovid was a commonplace echoed by many later authors. ${ }^{39}$ In Shakespeare alone, the shrieking of an owl heralds the murder of

${ }^{34}$ On the figure of Nobody, see Gerta Calmann, 'The Picture of Nobody: An Iconographical Study', Journal of the Warburg and Courtauld Institutes, 23 (1960), 60-104.

${ }^{35}$ Isidore of Seville, Etymologies, ed. by Stephen A. Barney and others (Cambridge: Cambridge University Press, 2006), 12. 7. 38-39. Isidore writes that the noctua is named 'because it flies around at night' and 'cannot see during the day', and is distinguished from the bubo on account of its smaller size (12.7. 40). The nycticorax, likewise, 'flees the light and cannot bear to look at sunlight' (12.7.41).

${ }^{36}$ Bartholomaeus Anglicus repeats Isidore's description of the bubo and extends it to the ulula because of its cry: De proprietatibus rerum, $12.5 ; 12.36$.

${ }^{37}$ John Maplet, A Greene Forest, or a Naturall Historie (London, 1567; STC 17296), N8 ${ }^{\mathrm{v}}$. The owl frequenting corpses, crypts, and sepulchres is repeated in Alciato's Emblemata, emblem 116, 'Senex puellam amans' $\left(\mathrm{I} 7^{\mathrm{r}}\right)$.

${ }^{38}$ Ovid, Metamorphoses, ed. by and trans. by Arthur Golding (London, 1567; STC 18956), $\mathrm{K} 1^{\mathrm{r}}, 5.538-50$.

${ }^{39}$ Geoffrey Chaucer was particularly fond of using the owl as an evil portent: see The Legend of Good Women, in which 'the oule al nyght aboute the balkes wond, | That prophete is of wo and of myschaunce' (lines 2253-54); The Parliament of Fowles, where 'the oule ek, that of deth the bode bryngeth' (line 343); and Book V of Troilus and Criseyde, in which Troilus bemoans, 'Al certeynly that I mot nedes dye. | The owle ek, which that hette Escaphilo, | Hath after me shright al thise nyghtes two' (lines 318-20). References to Chaucer are to The Riverside Chaucer, ed. by 
Duncan in Macbeth $(650,667$; II. 2. 3, 15), the forceful seduction of Adonis in Venus and Adonis (line 531), and Tarquin's lustful advances in The Rape of Lucrece (line 165). ${ }^{40}$

The association of the owl with prophecy and with folly was combined during the late Elizabethan and Jacobean debates about judicial astrology. As Nandini Das has argued, the growing appeal of astrology in post-Reformation England can be linked to 'the loss of the relics and the saints' of the old faith, resulting in a 'large void in the social machinery' that had previously served to assure the individual in times of strife and uncertainty. In place of these earlier practices, 'the increasing circulation of cheap, mass-produced almanacs and prognostications fed and nurtured a growing popular demand for the assurances offered by astrology'. ${ }^{41}$ At the same time, the popularity of these almanacs made them easy targets for burlesque and satire, whether ridicule was aimed at the authors or at astrology in general. ${ }^{42}$

Larry D. Benson, 3rd edn (Boston: Houghton Mifflin, 1987). In The Faerie Qveene (London, 1590; STC 23081), Edmund Spenser refers to 'the messenger of death, the ghastly owle' (E3 ${ }^{\mathrm{v}}$, 1. 5. 30) and the 'ill-faste Owle, deaths dreadfull messengere' $\left(2 \mathrm{~A} 3^{\mathrm{v}}, 2.12 .36\right)$.

${ }^{40}$ There are other instances in Shakespeare linking the owl to death: in 1 Henry VI, Talbot is called an 'ominous and fearefull Owle of death, | Our Nations terror, and their bloody scourge' (1965-66, IV. 2. 15-16) by one of the Dauphin's generals; in 3 Henry VI, by then a prisoner in the Tower, Henry tells Richard that 'The Owle shriek'd at thy birth, an euill signe' (3118, v. 6. 44) before he is murdered by Richard; and, following the revels in A Midsummer Night's Dream, Robin sweeps up with a broom 'Whil'st the scritch-owle, scritching loud, | Puts the wretch that lies in woe, | In remembrance of a shrowd' (2159-61, v. 2.6-8). Writing on Hamlet, Robert Tracy makes a compelling argument about Ophelia's comment that 'the O wle was a Bakers daughter' (2784-85, IV. 5. 41-42) is not only a foreshadowing of her imminent death, but suggests also her loss of virginity: 'The Owl and the Baker's Daughter: A Note on Hamlet', Shakespeare Quarterly, 17 (1966), 83-86.

${ }^{41}$ Nandini Das, Robert Greene's Planetomachia (1585) (Aldershot: Ashgate, 2007), p. xxv.

${ }^{42}$ Perhaps the most infamous case in point is that of Richard Harvey, whose failed predictions attracted censure and ridicule in books, ballads, and university drama. On the debate about judicial astrology in England, with a discussion of the Harvey affair, see Don Cameron Allen, The StarCrossed Renaissance (Durham: Duke University Press, 1941), esp. chaps 3-5. Other representative studies of astrology in early modern England include Lauren Kassell, Medicine and Magic in Elizabethan London: Simon Forman, Astrologer, Alchemist, and Physician (Oxford: Clarendon Press, 2005); Anne Geneva, Astrology and the Seventeenth Century Mind: William Lilly and the Language of the Stars (Manchester: Manchester University Press, 1995); Patrick Curry, Prophecy and Power: Astrology in Early Modern England (Princeton: Princeton University Press, 1989); Bernard Capp, English Almanacs, 1500-1800: Astrology and the Popular Press (Ithaca: Cornell University Press, 1979); and Keith Thomas, Religion and the Decline of Magic (New York: Charles Scribner's Sons, 1971). 


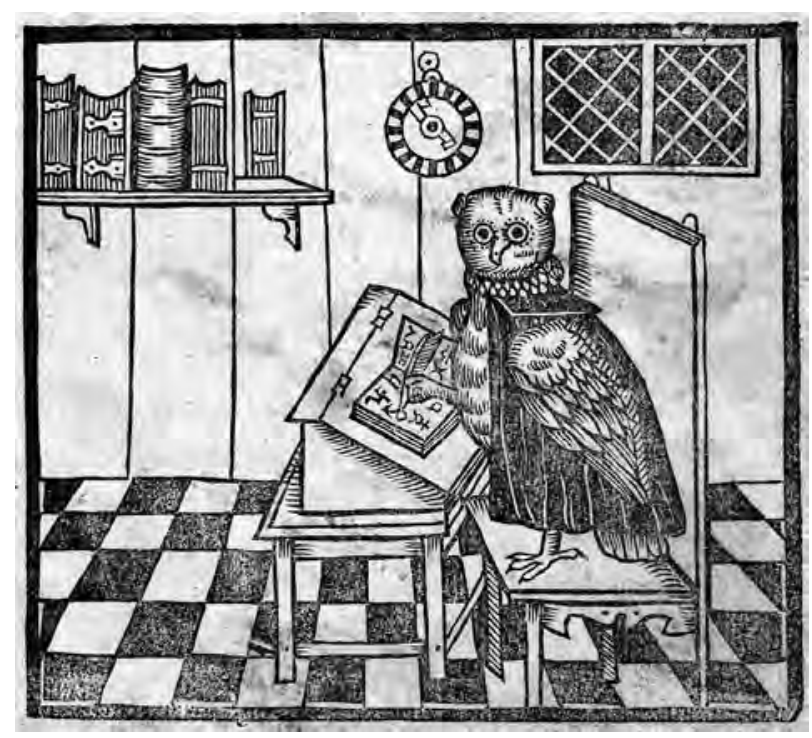

Figure 7. Title-page woodcut, The Owles Almanacke (London, 1618).

By permission of the Huntington Library, San Marino, CA.
One such parody is The Owles Almanacke (London, 1618; STC 6515), now ascribed to Thomas Middleton, ${ }^{43}$ which includes a custom title-page woodcut of an owl in scholarly garb scribbling his arcane prognostications in his study (Figure 7). The owl's various predictions for the year - that Ash Wednesday will fall 'on a Wednesday' $\left(\mathrm{Cl}^{\mathrm{r}}\right)$ and that 'More stinking breaths will be begotten by Tobacco this yeare, than children' $\left(\mathrm{E}^{\mathrm{r}}\right.$ ) - are as ridiculous as the owl's appearance in the woodcut. Drawing upon the owl's symbolic association with prophecy and with folly, the author of the Almanacke selected the most suitable candidate for his project to tar and feather astrologers and astrology.

Another lasting influence on the perception of the owl as a negative symbol came from the Bible. In Leviticus 11, the owl is listed among the birds that are unclean and detestable and, in the words of the Bishops' Bible, 'ought not to be eaten, for they are an abhomynacyon'. ${ }^{44}$ The belief that the owl was unclean was perpetuated in medieval bestiaries and stories, where the bird was accused of fouling its own nest. ${ }^{45}$ That the owl was often to be found skulking around crypts

${ }^{43}$ Neil Rhodes, 'The Owl's Almanac', in Thomas Middleton and Early Modern Textual Culture, ed. by Gary Taylor and John Lavagnino (Oxford: Oxford University Press, 2007), pp. 400-02.

${ }^{44}$ Evidently this biblical injunction was not enough to dissuade John Schroder, doctor of physic, from prescribing the flesh of the owl to cure 'the Paralytick, Melancholick, and the like', and the 'gall' and 'grease' of the owl as 'good against the spots of the eyes' and to sharpen vision: Zoologia, or, the History of Animals as they are Useful in Physick and Chirurgery (London, 1658; Wing S899), $\mathrm{H}^{\mathrm{r}}$.

${ }^{45}$ This is one of the charges made by the nightingale in The Owl and the Nightingale, ed. by Grattan and Sykes (lines 90-105). John Gower's Confessio Amantis also refers to the owl befouling 
and cemeteries could only have reinforced this perception. Indeed, the natural observation of owls being mobbed by smaller birds when they made the mistake of venturing out during the day was taken to be an indication of the hatred the owl inspired in other birds. ${ }^{46}$ Elsewhere, the Bible continued the owl's association with mourning: in his sorrow, Job is 'a companion to owles', his 'organe', like theirs, turned 'into the voyce of them that weepe'. ${ }^{47}$

Christian iconography was quick to appropriate the owl, a bird that lent itself nicely as an emblem of sin. As Jean Lambert has neatly summarized, on the one hand, the owl's 'night vision and daylight blindness suggested moral turpitude and religious blasphemy', while on the other, its 'daytime concealment indicated a turning away from and ignorance of the everyday affairs of the world'. ${ }^{48}$ Thus, the owl was routinely employed as the exemplum of the sin of sloth, since, in the words of John Maplet, the 'sluggard sleepeth all day long' despite having 'feathers inough to flie abrode day and night'. ${ }^{49}$ In addition, the owl's shunning of daylight

its own roost (3.585-86). References to Gower are to Complete Works, ed. by G. C. Macaulay (Oxford: Clarendon Press, 1901).

${ }^{46}$ The nightingale states that the owl is hated and mobbed by other birds in The Owl and the Nightingale, ed. by Grattan and Sykes (lines 60-70). This observation had been put to practical use since antiquity by fowlers, who used real and stuffed owls as bait: see Bartholomaeus, De proprietatibus rerum, 12. 5. The use of the owl to bait and trap was also used in allegories on lust and the folly of love in Germany and the Netherlands: see Keith P. F. Moxey, 'Master E. S. and the Folly of Love', Simiolus, 11 (1980), 125-48 (esp. pp. 134-37).

${ }^{47}$ Job 30, taken from the King James Version. Sixteenth-century English translations of both Job 30 and Micah 1 - including the Bishops' Bible, Coverdale Bible, Douay-Rheims Bible, Geneva Bible, Great Bible, and Matthew Bible — give 'ostriches' instead of 'owls'.

${ }^{48}$ Jean Lambert, 'Expounding the Owl: Ben Jonson's The Masque of Owls', Ben Jonson Journal, 15 (2008), 19-53 (p. 20). Lambert goes on to suggest that the identification of the owl as 'heresymonger' occurs in Alciato's Emblemata, which 'iconographically situates the sepulchral screech-owl among those condemned for religious non-conformity and superstitious beliefs' (p.21). While the owl is certainly often figured as an emblem of sin, heresy, and religious non-conformity, Lambert's assertion that this is present in Alciato is difficult to sustain. Neither of the two emblems containing owls employ the bird in this way: emblem 17 ('Prudens magis quam loquax') simply describes the wise owl replacing the garrulous crow as Minerva's counsel, whereas emblem 116 ('Senex puellam amans') has a jealous rival (Archippus) comparing the coupling of an old man (Sophocles) with a young woman (Aganippe) to a night owl sitting on a tombstone (noctua ut in tumulis) or a horned owl perching on a corpse (super utq[ue] cadauera bubo).

${ }^{49}$ Maplet, A Greene Forest, N8v. This is not to say that the owl was not characterized as idle in pre-Christian thought: for instance, Ovid calls the owl sluggish (ignauus bubo) in his Metamorphoses, 5.550 . 
parallelled the rejection of Christ by ignorant sinners, obstinate heretics, and the godless, a parallel often highlighted in medieval bestiaries: the caption to the owl illustration in a thirteenth-century aviarium (London, British Library, MS Sloane 278), 'infelix bubo: peccator homo' (fol. $31^{v}$ ), is a succinct and representative example. ${ }^{50}$

The symbolic identification of the owl with sinners in general in medieval visual culture was often refocused to represent the Jews in particular: just as the owl shuns the daylight and prefers the night, so too the Jews obstinately reject Christ and remain in the darkness of ignorance. As with the allegorical figure of Synagoga, blinded by a veil or fallen crown, the owl personified the blindness of the Jews. ${ }^{51}$ The owl's reputation as a filthy bird that soiled its own nest also resonated with antisemitic narratives linking the Jews to faeces, whether in the belief that the Jews had an offensive stench (foetor judaicus), ${ }^{52}$ or in the popular tale of the Jew of Tewkesbury, an event reported to have occurred in 1257:

${ }^{50}$ A notable exception to this general scheme is in the Aberdeen Bestiary (Aberdeen University Library, MS 24). While both bubo and noctua (fols $50^{\mathrm{r}}-51^{\mathrm{r}}$ ) are aligned with sinners, the nycticorax and its love of darkness is identified with Christ, who shuns vainglory and abides with sinners in order to convert them (fol. $35^{\mathrm{v}}$ ). This identification is expanded to all righteous men who, like the owl keeps watch at night, are vigilant against sin and sinners $\left(\right.$ fol. $36^{\mathrm{v}}$ ).

${ }^{51}$ The depiction of Synagoga defeated by Ecclesia was conventional in medieval religious art. In medieval England, representations of the pair in statues and stained glass appeared in Canterbury, Lincoln, Peterborough, and Rochester cathedrals. For a more detailed discussion of Synagoga/Ecclesia in medieval texts and art, see Margaret Schlauch, 'The Allegory of Church and Synagogue', Speculum, 13 (1939), 448-64; Lewis Edwards, 'Some English Examples of the Medieval Representation of Church and Synagogue', Transactions of the Jewish Historical Society of England, 18 (1958), 63-77; Wolfgang S. Seiferth, Synagogue and Church in the Middle Ages: Two Symbols in Art and Literature, trans. by Lee Chadeayne and Paul Gottwald (New York: Ungar, 1970); Heinz Schreckenberg, The Jews in Christian Art: An Illustrated History, trans. by John Bowden (New York: Continuum, 1996), chap. 3; Pamela Berger, 'The Roots of AntiSemitism in Medieval Visual Imagery: An Overview', Religion and the Arts, 4 (2000), 4-42; and Christine M. Rose, 'The Jewish Mother-in-Law: Synagoga and the Man of Law's Tale', in Chaucer and the Jews: Sources, Contexts, Meanings, ed. by Sheila Delany (New York: Routledge, 2002), pp. 3-24. On Jewish blindness, see Lampert, Gender and Jewish Difference from Paul to Shakespeare, chap. 2; and Edward Wheatley, "Blind” Jews and Blind Christians: Metaphors of Marginalization in Medieval Europe', Exemplaria, 14 (2002), 351-82.

52 The belief in the foetor judaicus was known in England, and apparently widespread enough for Thomas Browne to devote a chapter to refuting the charge 'that Jews stinck naturally' in his Pseudodoxia Epidemica (London, 1646; Wing B5159), 2C $1^{\mathrm{r}}-2 \mathrm{C} 3^{\mathrm{r}}$. 
A certain Jew [...] fell into a priuy at Tewkesbury vpon a sabboth day, which for the great reuerence he had to his holy sabboth, would not suffer him selfe to be plucked out. And so Lord Richard Earle of Glocester, hearing therof, would not suffer him to be drawne out on Sundaye for reuerence of the holy day. And thus the wretched superstitious Jewe remayning there tyll mondaye, was found dead in the doung. ${ }^{53}$

Although not evident in English culture, the contemporary German Judensau motif, with its depiction of Jews suckling a sow and feeding on her excrement, graphically reinforced this link. ${ }^{54}$

The identification of the Jews with bodily effluvia and waste has not escaped the attention of literary critics. For David Katz, the belief that Jewish men menstruated suggests that Shylock's question, 'if you pricke vs doe we not bleede?' (1275-76, III. 1.59-60), may have been interpreted as highlighting his Jewish difference, rather than as an expression of a shared humanity with his Christian interlocutors. ${ }^{55}$ Similarly, Jonathan Gil Harris has offered a provocative reading of Marlowe's Jew of Malta, where Barabas adopts the role of the excremental Jew, 'gain[ing] entry to the body politic through apertures that are subtly coded as its anus'..$^{56}$

In the textual and visual narratives of early English culture, the owl's affinity with the Jews extended beyond their shared blindness and filthiness. As Mariko Miyazaki has shown, images of owls in medieval bestiaries often reveal 'a focused attempt to anthropomorphize the bird' in such a way that it 'bears an unmistakable

${ }^{53}$ Foxe, Actes and Monuments, N1 1 . The story is also reported in John Stow, A Summarie of Englyshe Chronicles (London, 1565; STC 23319), M3 ${ }^{\mathrm{r}}$; Phillip Stubbes, The Anatomie of Abuses (London, 1583; STC 23377), M8v; Nicolas Bownde, The Doctrine of the Sabbath (London, 1595; STC 3436), Q1 ${ }^{\mathrm{r}}$; and the second edition of Robert Burton's Anatomy of Melancholy (Oxford, 1624; STC 4160), 3.4. 1.4 (3Z2 ${ }^{\mathrm{v}}$ ). Joan Young Gregg includes the tale as part of her collection of medieval exempla on Jews, noting continental variants as well as its use in a thirteenth-century French commentary on canon law: Devils, Women, and Jews: Reflections of the Other in Medieval Sermon Stories (Albany: State University of New York Press, 1997), pp. 214-16. For an insightful discussion of the tale and its reception in medieval England, see Bale, The Jew in the Medieval Book, chap. 2.

${ }^{54}$ On the Judensau motif, see Isaiah Shachar, The Judensau: A Medieval Anti-Jewish Motif and its History (London: Warburg Institute, 1974).

${ }^{55}$ David S. Katz, 'Shylock's Gender: Jewish Male Menstruation in Early Modern England', Review of English Studies, 50 (1999), 440-62. On the Jewish male menses, see Willis Johnson, 'The Myth of Jewish Male Menses', Journal of Medieval History, 24 (1998), 273-95; and Irven M. Resnick, 'Medieval Roots of the Myth of Jewish Male Menses', Harvard Theological Review, 93 (2000), 241-63.

${ }^{56}$ Jonathan Gil Harris, 'Public Enemas: The Disjunctions of the Excremental Jewish Pharmakon', in Foreign Bodies and the Body Politic: Discourses of Social Pathology in Early Modern England (Cambridge: Cambridge University Press, 1998), pp. 79-106 (p. 80). 


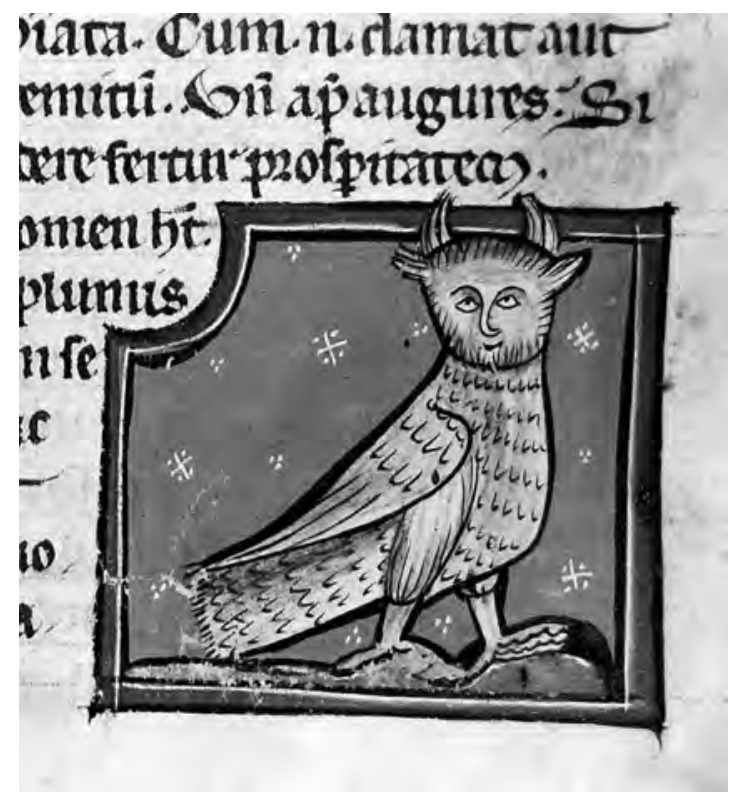

Figure 8. Horned owl with human face.

Westminster Abbey Bestiary, MS 22, fol. 40.

(C) The Dean and Chapter of Westminster Abbey. resemblance to contemporary portraits of Jews', giving the owl a 'recognizably human face' with a beak 'skillfully turned into a hooked nose'. ${ }^{57}$ The thirteenth-century Westminster Abbey Bestiary (MS 22) offers a pertinent example, where in addition to a human face and hooked nose the owl (bubo) is given horns - not just ears - easily identifiable with the horned hat the Jews were obliged to wear (Figure 8).

In the thirteenth-century Harley Bestiary (London, British Library, MS Harley 4751), an owl (bubo) is shown being mobbed by three smaller birds (Figure 9). Again, the owl is given a human face and hooked nose, and is thus identified with the Jews — hated by Christians just as the owl is by other birds.

As Miyazaki has shown in her survey of English bestiaries, even in cases where the owl has not been so graphically anthropomorphized, the images often include scriptural references linking the bird to the Jews: for instance, the owl (nycticorax) in the thirteenth-century Oxford Bestiary (Oxford, Bodleian Library, MS Bodley 602), 'shown closing its eyes and pecking a corpse in front of a collapsing temple [...] likely alludes to the ruin of Babylon and to the Synagogue, and thus to the destruction of the Old Law'.58

In the absence of any visual link, the bestiary text itself may make this connection. In some cases this may be explicit, such as in the so-called SecondFamily Latin bestiaries like the Aberdeen Bestiary (Aberdeen University Library,

${ }^{57}$ Mariko Miyazaki, 'Misericord Owls and Medieval Anti-Semitism', in The Mark of the Beast: The Medieval Bestiary in Art, Life, and Literature, ed. by Debra Hassig (New York: Garland, 1999), pp. 23-43 (p. 28).

${ }^{58}$ Miyazaki, 'Misericord Owls and Medieval Anti-Semitism', p. 28. 
MS 24), ${ }^{59}$ where the owl (noctua) 'symbolizes the Jews' (figuram gerit iudeorum) who rejected Christ's salvation and preferred darkness to light (fol. $\left.51^{\mathrm{r}}\right)$. Often the link is subtler, such as in the example Miyazaki offers of the owl (ulula) in Oxford, Bodleian Library, MS Bodley 764, where the text cites Isaiah 13, again referring to the destruction of Babylon. ${ }^{60}$

These antisemitic visual and textual narratives were not confined to the bestiary page, but

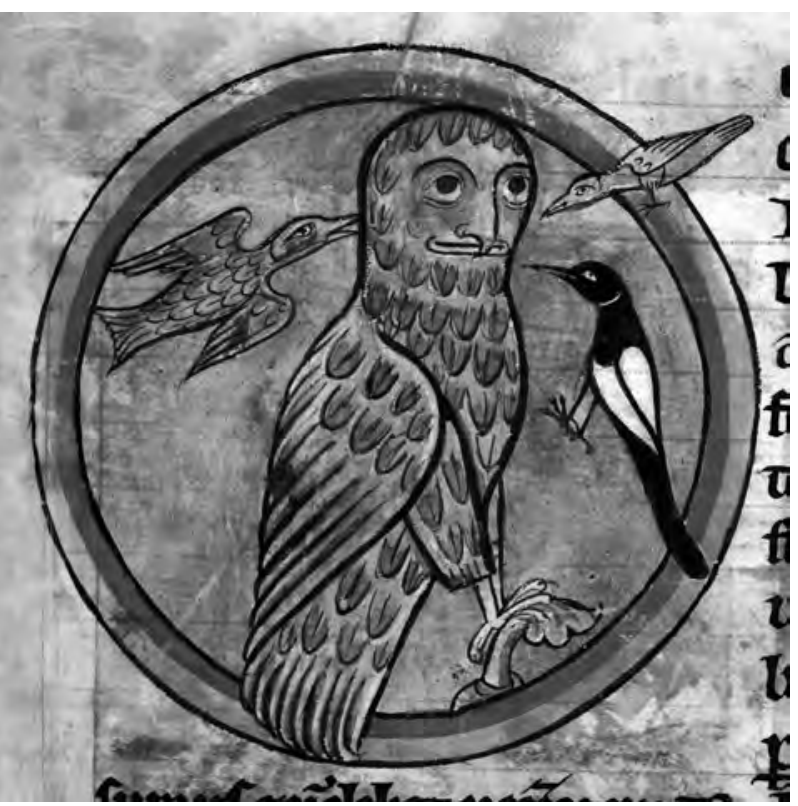

Figure 9. Owl mobbed by smaller birds. London, British Library, MS Harley 4751, fol. $47^{\text {r }}$. ( British Library Board, London. found their way into other genres and media. According to a twelfth-century poem attributed to Walter Map, Christ was put to death by owls (Christus a noctuis ad necem trabitur) and Christ was surrendered up for punishment by owls (Christus a noctuis datur supplicio). ${ }^{61}$ Moving from manuscript to architecture, Miyazaki has persuasively shown that medieval misericord and roof boss carvings of owls being mobbed in Norwich Cathedral (Figure 10) indicate the transmission and adaptation of bestiary owl

${ }^{59}$ The division of Latin bestiaries into families was proposed by M. R. James in The Bestiary (Oxford: Roxburghe Club, 1928) and refined by Florence McCulloch, Medieval Latin and French Bestiaries (Chapel Hill: University of North Carolina Press, 1960). For more detail about the classification, see the introduction and commentary in Willene B. Clark, A Medieval Book of Beasts (Woodbridge: Boydell, 2006).

${ }^{60}$ Miyazaki, 'Misericord Owls and Medieval Anti-Semitism', p. 28.

${ }^{61}$ The poem, which has been titled De Maria Virgine by its latest editor, is preserved in London, British Library, MS Cotton Titus A 20, fols 169 $-175^{\mathrm{v}}$, and is reprinted in The Latin Poems Commonly Attributed to Walter Mapes, ed. by Thomas Wright (London: Camden Society, 1841), pp. 191-207 (lines 419,423). The owl/crucifixion narrative may have been more widely circulated elsewhere in Europe: for example, the Antwerp Crucifixion by Antonello da Messina (c. 1475) depicts an owl alone in the foreground of the painting. 


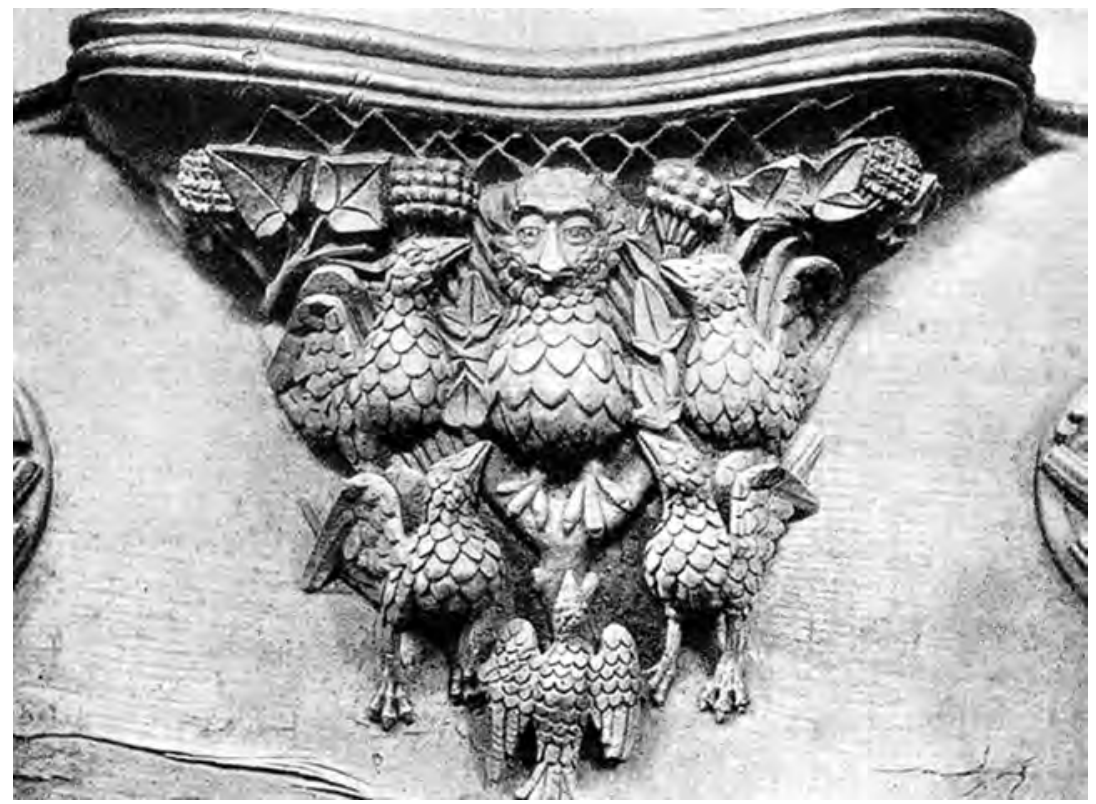

Figure 10. Owl mobbed by smaller birds. Carved misericord, Norwich Cathedral. Photograph by George C. Druce, F.S.A.

imagery into other media, through 'an acquaintance with bestiary stories by way of sermons and fables', making them 'especially relevant in public church settings' ${ }^{62}$

Like the carved owls in cathedrals across England that survived the iconoclasm of the Reformation, ${ }^{63}$ these medieval antisemitic narratives survived long after the Jews had been expelled from England. As Stephen Greenblatt so eloquently put it, 'the Jews left traces far more difficult to eradicate than people, and the English brooded on these traces - stories circulated, reiterated, and elaborated - continually and virtually obsessively', and the emblematic owl is but one of many of these traces that 'played a powerful role in the country's imaginative economy'. ${ }^{64}$ Drawing on this imaginative economy, devotees like William Austin could berate those 'Owle-eyed Iewes [...] that loved darknesse, better then Light', ${ }^{5}$ in much the same way that readers of Aemilia Lanyer's Salue Deus Rex Iudaeorum could appreciate

${ }^{62}$ Miyazaki, 'Misericord Owls and Medieval Anti-Semitism', p. 24.

${ }^{63}$ Carvings of owls survive in Exeter, Gloucester, Lincoln, and W inchester cathedrals.

${ }^{64}$ Stephen Greenblatt, Will in the World: How Shakespeare Became Shakespeare (New York: Norton, 2004), p. 258.

${ }^{65}$ William Austin, Devotionis Augustinianae Flamma (London, 1635; STC 972), p. 197. 
her rebuke of Caiaphas, failing to apprehend Christ's divinity for his 'Owly eies are blind, and cannot see'. ${ }^{66}$

One final example of the Jew/owl motif as it appears in early modern England deserves closer inspection. Thomas Palmer's Two Hundred Poosees (c. 1565), the earliest English emblem book surviving in an autograph manuscript (London, British Library, MS Sloane 3794), contains the emblem of 'The blinde Iue':

The Oule dothe flie abrode to get suche meate as he dothe lacke,

And sees it beste, when that the nighte eche thinge hathe died blacke.

But when the Sonne with christall beames hathe whitened all againe,

Then he perceaves his sighte to faile, and takes no farther payne.

The Iue dothe flee the lighte of christe, and glories in the Lawe:

What saide I then? he was an Oule? no, no, he is a dawe. ${ }^{67}$

Palmer's emblem makes the common pun on 'Sonne' as both the sun and the Son, linking the owl's aversion to daylight with the Jewish rejection of Christ. For those readers who perhaps failed to grasp the initial pun, Palmer follows with less elusive wordplay, giving the sun/Son 'christall beames' (emphasis mine) The blindness of Palmer's Jew, who 'glories in the Lawe', is wilful obstinacy rather than simple ignorance, drawing upon a long tradition of representing the Jewish inability to accept the supersession of the Old Law by the New.

Interestingly, in the final couplet, the Jew is reimagined as a 'dawe' or jackdaw, a bird known for its garrulousness and often used as an epithet for gossips, scolds, and railers. ${ }^{68}$ This characterization of the jackdaw was expanded in medieval

${ }^{66}$ Aemilia Lanyer, Salue Deus Rex Iudaeorum (London, 1611; STC 15227), C4 $4^{\mathrm{r}}$ (line 712). On the question of Lanyer's purported Jewish ancestry, see Alessio Ruffatti, 'Italian Musicians at the Tudor Court: Were They Really Jews?', Transactions of the Jewish Historical Society of England, 35 (2000), 1-14.

${ }^{67}$ Thomas Palmer, Two Hundred Poosees (BL, MS Sloane 3794), emblem 198, as transcribed in The Emblems of Thomas Palmer: Two Hundred Poosees, Sloane MS 3794, ed. by John Manning (New York: AMS Press, 1988). The last hundred emblems lack pictura, with Palmer simply providing descriptions of the intended image. In the case of emblem 198, the pictura Palmer had in mind was of 'the Oule fleinge by nighte'.

${ }^{68}$ See, for example, John Florio's definitions for the Italian gracchia and taccola in $A$ Worlde of Wordes (London, 1598; STC 11098), p. 153, p. 410. 
bestiaries, such as in the Aberdeen Bestiary (fol. $51^{v}$ ), where the bird signifies the vain chatter of philosophers (philosophorum vanam loquacitatem) and the noxious verbosity of heretics (bereticorum verbositatem noxiam). Further, converts learn the words of religion (verba religionis) just as the jackdaw can be taught the words of men (fol. $52^{\mathrm{r}}$ ). Given the increased number of converted Jews (conversos) and secret Jews (marranos) in Europe (as well as England) following their expulsion from Spain and Portugal at the close of the fifteenth century, Palmer's emblem perhaps resonates with sixteenth-century anxieties about these resident aliens and their uncertain religious allegiances. ${ }^{69}$

\section{The Owl-light of Rome}

Polemics on all sides during the various European Reformations of the sixteenth century took great pains to denigrate the beliefs and personalities of the opposition, with the advent of moveable type allowing the war for the souls of Christendom to extend beyond the limited hearing range of the pulpit. Libels issued from both camps were quick to emphasize the monstrosity, carnality, and diabolism of the other, and in doing so often relied on the Jews, a tried-and-true symbol embodying all of these abject qualities. For the Reformers, the pope was not simply a monster — as in the satirical woodcut depiction of the Bapstesel, ${ }^{70}$ or 'Pope Ass' - but the head of the 'Synagogue of Satan', a phrase originally found in the Book of Revelation that became a popular epithet in medieval polemics against the Jews. ${ }^{71}$ The attacks of Luther and other Reformers therefore continued 'a long tradition of

${ }^{69}$ The Jew as daw motif also occurs in Andrew Boorde's popular treatise, The Fyrst Boke of the Introduction of Knowledge (London, 1555; STC 3383), where the figure of the Jew expresses the fear that 'at lenghth I shall proue a daw' $\left(\mathrm{N} 2^{\mathrm{v}}\right)$.

${ }^{70}$ As Alain Boureau neatly summarizes, 'In 1496 a monstrous cadaver was fished out of the Tiber: a she-ass with a female human torso, the arms and legs of a variety of animals, and a dragonlike tail. It was immediately baptized "the Papal Ass" (Die Bapstesel zu Rom). The engraver Wenzel von Olmutz depicted the prodigy and published his image, with an antipapal exegesis, in Bohemia in the late fifteenth century. From there the image passed into Germany [...] and in 1523 Luther and Melanchthon published illustrations and commentary on the Papal Ass and another prodigy, the Monk Calf [...] The images were a wild success: the paired figures together went through nine editions, with five editions of the Papal Ass alone and a number of translations into French, English, and Dutch': The Myth of Pope Joan, trans. by Lydia G. Cochrane (Chicago: University of Chicago Press, 2001), p. 233.

${ }^{71}$ Revelation 2. 9, 3. 9; see Strickland, Saracens, Demons, and Jews, p. 128. 
identifying Babylon with the Roman Catholic Church', ${ }^{72}$ one that had earlier 'offered medieval heretics a needed critique of the established faith'. ${ }^{73}$ The sheer number of treatises against the ceremonies of the 'Romish Synagogue' and the rituals of the 'Synagogue of Satan' printed in early modern England is evidence of the lasting popularity and utility of the label.

Where the taint of Jewishness was alleged, the symbolic association of the owl was sure to follow: in the highly charged sectarian debates of the sixteenth century, the owl - the popular symbol of Jewish blindness, filth, and folly - became associated with Catholics. ${ }^{74}$ In England, Reformers like John Bale admonished papists for being 'lyke $[\ldots]$ the owle, whyche seeth all in the darke, and nothyng in the clere lyght'. ${ }^{75}$ In De Byen Corf der H. Roomsche Kercke (Amsterdam, 1569), translated into English in 1579, the Flemish exile Philips van Marnix would draw upon the association of the owl with blindness and sloth in his satire on the 'bee hive of the Romish Church', in which the priests

Make their eyes as dim as an Owle: they watche by night, to sleepe in the day: they forsake their owne riches and substance, to liue on the sweate of other mens browes: they labour neuer a whit, to the ende they may enter into more deepe contemplations. ${ }^{76}$

Like the charge of judaizing, the 'owle-eyed' blindness of Catholics became a stockstandard slur in English Protestant polemic well into the seventeenth century. ${ }^{77} \mathrm{An}$

${ }^{72}$ Judith L. Kovacs and Christopher Rowland, Revelation: The Apocalypse of Jesus Christ, Blackwell Bible Commentaries (Malden: Blackwell, 2004), p. 55.

${ }^{73}$ Nathan Johnstone, The Devil and Demonism in Early Modern England (Cambridge: Cambridge University Press, 2006), p. 29.

${ }^{74}$ The title-page woodcut of the second part of Martin Luther's controversial pamphlet Wider die Himmlischen Propheten, von den Bildern und Sakrament (Erfurt, 1525) features an owl and cites II Timothy 3, 'their folly shall be evident to all men' (Calmann, 'The Picture of Nobody', p. 67, n. 47). Later, Luther would be himself slighted as an owl by way of a facetious comment made by the Catholic controversialist John Sergeant in his Errour Non-Plust (London, 1673; Wing S2565), 'All slept, and were wrap't up (God wot) in the dark night of Ignorance, till owl-ey'd Luther even at that mid-night of Infidelity most blessedly esp'd the Light of the Gospel dawning' (2F4v).

${ }^{75}$ John Bale, The Apology of Iohan Bale Agaynst a Ranke Papyst (London, 1550; STC 1275), lvir.

${ }^{76}$ Philips van Marnix, The Bee Hiue of the Romishe Church, trans. by George Gilpin (London, 1579; STC 17445), 2N3v.

77 Representative examples include Andrew Willet, A Retection, or Discouerie of a False Detection (London, 1603; STC 25694), A3 ${ }^{\mathrm{v}}$; George Closse, The Parricide Papist, or Cut-throate Catholic (London, 1606; STC 5441), B4둘 Henry Burton, A Plea to an Appeale (London, 1626; STC 4153), L4루 Thomas Dering, The Foure Cardinall-Vertues of a Carmelite-Fryar (London, 1641; Wing D1109), B4" 
oft-cited episode from ecclesiastical history - a topic of renewed interest at the time - would reveal an additional link between the papacy and the owl. The story, perhaps more fiction than fact, takes place at a council called by the fifteenthcentury antipope John XXIII in Rome, where, after 'a Masse of the holy Ghost being sayd' and those present having taken their seats,

A hougly and dreadefull Owle [...] flew to and fro, with her euill fauoured voyce, \& standyng vpo[n] the middle beame of the church, cast her staryng eyes vpon the pope sittyng, the whole company began to maruell [...] For behold sayd they, (whisperyng one in anothers eare) the spirite appeareth in the shape of an Owle. And as they stode beholding one an other, $\&$ aduising the Pope, skarsly could keepe their countenaunce fro[m] laughter, Iohn him self, vpon whom the Owle stedfastly looked, blushyng at the matter, began to sweat and to freat [...] beyng so confused dissoluyng the Councell, rose $\mathrm{vp}$ and departed. After that there folowed an other session. In the which the Owle again, after the maner aforesayd [...] was present lookyng stedfastly vpon the Byshop, whom hee beholdyng to be come agayne, was more ashamed then he was before (and iustly) saying hee could no longer abyde the sight of her, \& com maunded that she should be driuen away with battes and shottinges: but she beyng afraid neither with their noyse, neither of any thyng els, would not away, vntill that with the strokes of the stickes, which were throwne at her, she fell downe dead before the $[\mathrm{m}]$ all. $^{78}$

While Foxe doubted the authenticity of the story — 'scarsly credityng [it] for the rarenes of the matter' - other commentators were not so concerned. For them, the event offered a poignant case of Catholic superstition - that the owl could be the Holy Spirit - and, depending on whether the owl actually was the Holy Spirit or not, blasphemy or folly. For example, as part of his discussion of 'the wicked lives, and wofull deaths of the Popes, and Popelings', Samuel Clarke concludes the story by citing II Thessalonians 2 . 8: 'then shall that wicked one be revealed, whom the Lord shall consume with the spirit of his mouth and shall destroy with the brightness of his coming. ${ }^{79}$ Viewed as an indication of divine condemnation

${ }^{78}$ Foxe, Actes and Monuments, $2 \mathrm{P} 5^{\mathrm{r}-\mathrm{v}}$. The ultimate source of the tale is Nicolas de Clamanges, Disputatio super materia Concilii Generalis, printed in Fasciculus rerum expetendarum et fugiendarum (Cologne, 1535), p. 201. The story is repeated, often with added anti-Catholic vitriol, in various sixteenth- and seventeenth-century English treatises, including Christopher Carlile, $A$ Discourse [...] That Peter was Neuer at Rome (London, 1572; STC 4655), L3 $3^{\mathrm{v}}$; John Bale, A Pageant of Popes, trans. by John Studley (London, 1574; STC 1304), pp. 156-57; John Lupton, The Christian Against the Iesuite (London, 1582; STC 14946), 49 ${ }^{\mathrm{r}-\mathrm{v}}$ and $93^{\mathrm{r}}$; George Wither, $A$ View of the Marginal Notes of the Popish Testament (London, 1588; STC 25889), B3 ${ }^{\text {r }}$ Andrew Willet, Synopsis Papismi (London, 1592; STC 25696), pp. 90-91; and Alexander Cooke, Pope Ioane (London, 1625; STC 5660), G3 .

${ }^{79}$ Samuel Clarke, A Mirrour or Looking-Glasse both for Saints and Sinners (London, 1646; Wing C4548), F7 ${ }^{\mathrm{r}}$. 
during the Western Schism, the story of the owl and the Council at Rome was absorbed into an increasing arsenal of anti-Catholic narratives during the Reformations of the sixteenth century.

Under Elizabeth, as Christopher Haigh has famously noted, England became 'a Protestant nation, but not a nation of Protestants' ${ }^{80}$ Catholicism was not simply a spectre from the past, but a real presence:

For even after more than three decades of official Protestantism, committed Catholics were still to be found in England. Catholicism survived and even thrived in several surreptitious guises. Wealthy recusants, long-standing noble families whose attachment to the old religion could easily outlive Tudor monarchs, were able to keep priests as part of their households, and to pay the stiff fines for non-attendance at church. 'Church papists' practised their religion privately while outwardly conforming. And after the pope's excommunication of Elizabeth in 1570, Jesuit priests, most of them Continentally educated sons of English Catholic families, attempted to continue Mary I's work of Counter-Reformation, transforming it into a missionary movement. ${ }^{81}$

Whether they outwardly conformed as 'church papists' or refused to attend the Protestant service as recusants, Catholics in early modern England were seen as remaining in the darkness of the 'owle-light of Rome'. ${ }^{82}$ Anthony Nixon's Romes Downefall, one of three poems written to celebrate the accession of James I in 1603 , succinctly captures the popular anti-Catholic sentiment of the times:
Vanish away ye birds of vgly night,
Which with the Owle ca[n]not endure the light;
The light hath all your knauerie bewrai'd,
And to the view of all the world it laid.
Your neasts are found, your filthinesse descride,
Then pack away, no longer here abide. ${ }^{83}$

Here, as before with the Jews in medieval narratives, Catholics are figured as blind, foolish and deceitful ('knauerie'), filthy, and unwelcomed owls and 'birds of vgly night'. Similarly, in Phineas Fletcher's allegorical poem, The Purple Island, Catholicism is represented by the figure of 'Owl-ey'd Superstition', who is

${ }^{80}$ Christopher Haigh, The English Reformations: Religion, Politics, and Society under the Tudors (Oxford: Clarendon Press, 1993), p. 280.

${ }^{81}$ Lori Anne Ferrell, 'Religious Persuasions, c. 1580-c. 1620', in Companion to Renaissance Drama, ed. by Arthur F. Kinney (Malden: Blackwell, 2002), pp. 40-49 (p. 44).

${ }^{82}$ Willet, A Retection, or Discouerie of a False Detection, A3 ${ }^{\mathrm{v}}$.

${ }^{83}$ Anthony Nixon, Elizaes Memoriall, King Iames his Arriuall, and Romes Downefall (London, 1603; STC 18586), D2 $2^{\mathrm{r}}$. 
Deform'd, distorted, blinde in shining light;

Yet styles her self holy Devotion,

And so is call'd, and seems in shadie night:

Fearfull, as is the hare, or hunted hinde;

Her face and breast she oft with crosses sign'd:

No custome would she break, or change her setled minde. ${ }^{84}$

Again, the owl is linked with Catholic blindness, folly, superstition, and abjectness ('deform'd, distorted'). Moreover, Fletcher's reference to the 'hunted hinde' surely would have brought to mind a particular group of Catholics, namely the Jesuit priests whom the Tudor and Stuart authorities were increasingly keen to apprehend and prosecute as conspirators and traitors to the Crown. It is unsurprising then that the Jesuits would be the next group to be maligned as owls in the early modern English imagination. In 1580, Edmund Campion and Robert Persons led the first Jesuit mission to England, and after several months in the country, Persons published his defence of recusancy, A BriefDiscours Containing Certayne Reasons Why Catholiques Refuse to Goe to Church (London, 1580; STC 19394). Among other reasons, Persons argued that Catholics refused to attend the Protestant Churches out of religious conviction, not out of contempt for the Crown. Although Persons signed the introductory epistle dedicated to Elizabeth as 'I. Howlet' $\left(2 \neq 8^{v}\right)$, the authorities were quick to ascertain the identity of its author.

In the meantime, his choice of pseudonym would prove to be unfortunate. An owlet/howlet is an infant or small owl, and as Malcolm South notes, this 'was immediately seized upon by the controversialists who answered Persons' ${ }^{35}$ The title of William Fulke's response attacked Persons's 'popish discourse' as 'presumptuously dedicated to the Queenes most excellent Maiestie' as by 'Iohn Howlet, or some other birde of the night'. ${ }^{86}$ Perceval Wilburn's 'briefe confutation' was aimed at Howlet's 'vntimely schreeching in her Maiesties eares', in which Howlet is described as a 'foule and vnluckie bird' which 'schritchith an[d] maketh an yll fauoured noyse'. ${ }^{87}$ As a final example, John Fielde's response called Howlet 'an obscure owle' that 'fluttered foorth in the broade day and skriched oute in her

${ }^{84}$ Phineas Fletcher, The Purple Island, or, the Isle of Man (Cambridge, 1633; STC 11082), $\mathrm{M} 44^{\mathrm{r}}$.

${ }^{85}$ Malcolm H. South, 'The "Vncleane Birds, in Seuenty-Seuen": The Alchemist', Studies in English Literature, 1500-1900, 13 (1973), 331-43 (p. 332).

${ }^{86}$ William Fulke, A Briefe Confutation, of a Popish Discourse (London, 1581; STC 11421).

${ }^{87}$ Perceval Wilburn, A Checke or Reproofe of M. Howlets Vntimely Schreeching in Her Maiesties Eares (London, 1581; STC 25586), title-page, $\mathrm{A}^{\mathrm{v}}{ }^{\mathrm{v}}$ (where Elizabeth I is figured as the nightingale), $\mathrm{A} 2^{\mathrm{r}}$. 
Maiesties eares', along with 'all the rest of that darke brood' of 'owles and vncleane birds' like him that sought 'the discredite of the trueth, and the disquiet of this Church of England' ${ }^{88}$ Persons never published under the name Howlet again.

Jesuit involvement in Catholic plots, both real and imagined, further cemented identification with the owl. In The Whore of Babylon, Thomas Dekker's thinly veiled allegorical staging of the various failed Catholic attempts on Elizabeth's life, the counsellor Parthenophil (William Cecil) informs the Fairy Queen Titania (Elizabeth) of the capture of Campeius (Edmund Campion), describing him as an 'Owle, that did not love [her] sacred light', who 'Stole or'e the Seas by darknes, and was held | In Babilon [Rome] a bird of noble flight'. ${ }^{99}$ The failed Gunpowder Plot of 1605, which implicated the Jesuit Henry Garnett, gave popular anti-Catholic sentiment renewed vigour. Published only a few months following the plot, Dekker's The Double PP (that is, PoPe) focuses much vitriol on the Jesuits, and includes the following character sketch:
A Papist Vmbreant (like a Skreech-owle) sits
All day vnseen: but when the sorcerous night
Spreds her deepe Spells, hee coniures vp his wits,
Giuing his soule to Treason: hee's a Sprite
That deales in Fire-workes: Vaults are his delight,
Where for his close Traynes, hell does him prefer
To be Arch-Enginist to Lucifer. ${ }^{90}$

Although clearly directed at Guy Fawkes, Dekker's sketch of the 'Papist Vmbreant' resonates with other descriptions of the Jesuits. Likened to 'a Skreech-owle', the 'Papist Vmbreant' recalls Robert Persons and his fellow 'birds of night'. Earlier in the pamphlet is 'the Pictvre of a Iesuite', in which Dekker plays upon the Jesuit use of disguise, equivocation, and secrecy to become anyone or anything: 'Hee's Brown, hee's Gray, hee's Black, hee's white, |He's Any thing [...] A Jesuit' (B1 $\left.{ }^{v}\right)$. References to vaults and engines in the image of the 'Papist Vmbreant' similarly echo Dekker's earlier 'Pictvre' of a Jesuit as having 'two Engines' for legs, which are part of his arsenal of mimicry: 'like the vaulting horses legs', they are made longer or shorter through use of 'Iron pegs' $\left(\mathrm{A} 3^{v}\right)$. Thus able to transform themselves and moving

${ }^{88}$ John Fielde, A Caueat for Parsons Howlet (London, 1581; STC 10844), title-page, A4 ${ }^{\mathrm{r}}, \mathrm{F}^{\mathrm{v}}$.

${ }^{89}$ Thomas Dekker, The Whore of Babylon (London, 1607; STC 6532), H1 ${ }^{\mathrm{r}}$. For a recent discussion of the play and its use of nostalgia to covertly critique the Jacobean court, see Susan E. Krantz, 'Thomas Dekker's Political Commentary in The Whore of Babylon', Studies in English Literature, 1500-1900, 35 (1995), 271-91.

${ }^{90}$ Thomas Dekker, The Double PP (London, 1606; STC 6498), D2 ${ }^{\mathrm{r}}$. 
under cover of darkness, Jesuit missionaries were imagined to roam the English countryside in secret 'night walks like owles'. ${ }^{91}$

As Malcolm South has persuasively shown, by the time Ben Jonson penned The Alchemist, the association between owls and other 'vncleane birds' and 'Catholics and missionary priests' had been established in England 'for a number of years'. In the play, the Puritan Ananias rebukes Surly, disguised as a Spaniard, saying

Thou art not of the light. That Ruffe of pride,

About thy neck, betrayes thee: 'and is the same

With that, which the vncleane Birds, In seuenty-seuen,

Were seene to pranke it with, on diuers coasts. ${ }^{93}$

Jonson's audience certainly would have appreciated the more sinister implications of Ananias's rebuke: that Surly's ruff 'betrayes' him as a Catholic, as it is the 'same' as those worn by the 'vncleane Birds, in seuenty-seven', that is, the seminary priests who wore ruffs of the Spanish style as part of their disguise as courtiers. These 'vncleane Birds' are no doubt owls, whose round faces framed with feathers resemble ruffs: Mildmay Fane would later describe the 'Owl' in a poem as 'Rufft like a Judge'. ${ }^{94}$ As South suggests, Jonson's 'seuenty-seuen' might refer to 1577 as the year in which Cuthbert Mayne became the first of these fugitive priests to be executed in England. ${ }^{95}$

Whether or not this is the case, ${ }^{96}$ or Jonson had another event of 1577 in mind, it is clear that by the time of the first performance of The Alchemist the link between owls and Catholics in general, and Jesuits and seminary priests in particular, was common enough to be readily identifiable. Both Jonson and Dekker could reasonably expect their audiences to recognize their use of the language of sectarian symbolism, manifest in print and pulpit, which held that Catholics followed the

${ }^{91}$ George Whetstone, The Censure of a Loyall Subiect (London, 1587; STC 25334), D2 ${ }^{\mathrm{r}}$.

${ }^{92}$ South, 'The "Vncleane Birds, in Seuenty-Seuen"', p. 335.

${ }^{93}$ Ben Jonson, The Alchemist (London, 1612; STC 14755), K4v

${ }^{94}$ Mildmay Fane, 'My Happy Life, To A Friend', Otia sacra optima fides (London, 1648; Wing W 1476), p. 137.

${ }^{95}$ South, 'The "Vncleane Birds, in Seuenty-Seuen"', p. 338.

${ }^{96}$ Sightings of monstrous birds with ruffs off the Lincolnshire coast in 1586 were reported in a pamphlet (STC 6074a.7), prompting M. A. Shaaber to suggest an allusion by Jonson: 'The "Vncleane Birds" in The Alchemist', MLN, 65 (1950), 106-09. Shaaber's unsatisfactory explanation was adopted by Gordon Campbell, who glosses the passage in his edition of the play for the Oxford English Drama series, adding 'Ananias is probably alluding to a later visitation' of the monstrous birds: The Alchemist and Other Plays (Oxford: Oxford University Press, 1995), p. 501. 
'whore of Babylon', a pope who 'flieth the light of the Scriptures, and loveth the darke night of ignorance', whose 'Priests and Iesuites sculke and lurke [...] in dens and thickets of ignorance' and as 'Owles and Bats flutter abroad [...] in the twilight' to incite rebellion and bring about the ruin of Protestant England. ${ }^{97}$

\section{Owls and Purblind Puritans}

The Roman Catholic Church was not alone in being tarnished with the stigma of Jewishness, as the various Protestant groups that emerged during the sixteenth century were quick to paint their rivals, Papists and Reformers alike, with the same brush: whether Catholic or Protestant, the charge of judaizing became 'an all-tooconvenient, pejorative epithet' that could be (and was) levelled at anyone, regardless of creed.$^{98}$ Jerome Friedman illustrates the situation succinctly as follows:

The Lutheran author Hunnius described John Calvin as a judaizer [in his Calvinus Iudaizans (Wittenberg, 1595)] much as Calvin believed Lutheran liturgy was highly judaistic. On the other hand, Roman Catholic spokesmen thought Lutheran preoccupation with scriptural literalism was judaistic while both Reformed and Lutheran thinkers assumed Roman Catholic interest in ceremony and ritual reflected judaizing tendencies. ${ }^{99}$

In much the same way that English Protestants stigmatized Catholic pomp and ceremony as a regression to Judaism, the charge of judaizing also formed part of the 'virulent polemic of denunciation of those who sought any further reform of the English Church'. ${ }^{100}$ William Gouge's irritation at the branding of his fellow

${ }^{97}$ Thomas Taylor, Two Sermons (London, 1624; STC 23853), B4 ${ }^{\mathrm{v}}$. In another sermon, published posthumously as Evangelicall Sacrifices in XIX Sermons (London, 1640; STC 22491), Richard Sibbes urged parents and teachers to have 'more care of catechising' and 'of grounding young ones in the ground of Religion', since 'the neglect of this [...] hath made them fit for Iesuits and Priests to work on'. As 'Popery is a Kingdome of darkness', education serves to 'set up lights that may shine; for these Owles fly in the darke, they cannot endure the light' (pp. 122-23).

${ }^{98}$ Allison P. Coudert, The Impact of the Kabbalah in the Seventeenth Century (Leiden: Brill, 1999), p. 104.

${ }^{99}$ Jerome Friedman, The Most Ancient Testimony: Sixteenth-Century Christian-Hebraica in the Age of Renaissance Nostalgia (Athens: Ohio University Press, 1983), p. 182. On the ways in which the charge of judaizing was used by various sides in the Reformation debates, see Róbert Dán, 'Judaizare: The Career of a Term', in Antitrinitarianism in the Second Half of the 16th Century, ed. by Róbert Dán and Antal Pirnát (Leiden: Brill, 1982), pp. 25-34.

${ }^{100}$ Lori Anne Ferrell, Government by Polemic: James I, the King's Preachers, and the Rhetorics of Conformity, 1603-1625 (Stanford: Stanford University Press, 1998), p. 9. 
reformers 'with ignominious titles, as Precisians, Puritanes, Sabbatarians, and Jewes ${ }^{101}$ is representative of the way in which these various groups were conflated and maligned by virtue of the perceived Jewish tendencies they shared: privileging Old Testament values and espousing the literal interpretation of scripture. Robert Burton, after recounting the story of the Jew who fell into a privy at Tewkesbury, concludes his discussion of religious melancholy by stating that 'we have myriads of examples in this kind'. ${ }^{102} \mathrm{~A}$ sermon by John Howson offers one of the contemporary examples Burton alludes to: of those that 'doe Iudaize' and 'will see their neighbour perish before they will relieue him on the Sabboth day', Howson tells of an Oxfordshire man 'who lately when his fathers ribbes were broken would not ride for a bone-setter on the Sabboth day'. ${ }^{103}$

Criticism of Puritans was not confined to print or pulpit. The English stage 'had good reasons for hating the Puritan', and 'he did lend himself in an obvious manner to comic caricature with material as rich and as rewarding as the old vice. ${ }^{104}$ Indeed, the influence of the theatre's use of the stock figure has led Patrick Collinson to suggest that the stage was instrumental in the cultural construction of Puritan identity itself. ${ }^{105}$ In addition to their hypocrisy, religious fervour, and snobbery, stage Puritans were mocked for their subscription to Jewish beliefs and practices, such as abstaining from pork or observing the Jewish Sabbath. Examples include 'Rabbi' Zeal-of-the-Land Busy in Jonson's Bartholomew Fair, or the Puritan figure

${ }^{101}$ William Gouge, The Sabbaths Sanctification (London, 1641; Wing G1395), E3 ${ }^{\mathrm{v}}$. On the vilification of Puritans as Jews in early modern England, see Nicholas McDowell, 'The Stigmatizing of Puritans as Jews in Jacobean England: Ben Jonson, Francis Bacon and the Book of Sports Controversy', Renaissance Studies, 19 (2005), 348-63.

${ }^{102}$ Burton, Anatomy of Melancholy, $3 \mathrm{Z2}^{\mathrm{v}}$

${ }^{103}$ John Howson, A Sermon Preached at St. Maries in Oxford (London, 1602; STC 13884), $\mathrm{C} 1^{\mathrm{r}}$.

${ }^{104}$ William P. Holden, Anti-Puritan Satire, 1572-1642 (New Haven: Yale University Press, 1954), p. 101.

${ }^{105}$ Patrick Collinson, 'Ben Jonson's Bartholomew Fair: The Theatre Constructs Puritanism', in The Theatrical City: Culture, Theatre and Politics in London, 1576-1649, ed. by David L. Smith, Richard Strier, and David Bevington (Cambridge: Cambridge University Press, 1995), pp. 157-69. See also Patrick Collinson's essay, 'Ecclesiastical Vitriol: Religious Satire in the 1590s and the Invention of Puritanism', in The Reign of Elizabeth I: Court and Culture in the Last Decade, ed. by John Guy (Cambridge: Cambridge University Press, 1995), pp. 150-70. For challenges to the dominant stereotypes of religious non-conformity, see Kristen Poole, Radical Religion from Shakespeare to Milton: Figures of Nonconformity in Early Modern England (Cambridge: Cambridge University Press, 2000). 
appearing as part of the 'anticke round of dancers' in Robert Davenport's $A$ New Tricke to Cheat the Divell, who announces:

I am a Puritan $[\ldots]$ one that will eate no Porke,

Doth use to shut his shop on Saterdayes,

And open them on Sundayes: a Familist;

And one of the Arch limbes of Belzebub,

A Iewish Christian, and a Christian Iew. ${ }^{106}$

Here, as elsewhere, the stage Puritan is not simply a caricature of a Jew, but a complex conflation of various identities: he is at once a Sabbatarian (one who adheres to the Saturday Sabbath of the Old Testament), a Familist (a member of the heretical Family of Love), a Christian, and a Jew — and, as 'one of the Arch limbes of Belzebub', he could be aligned with the Catholic Church or any number of unorthodox religious groups. In constructing the Puritan as an amalgam of deviant identities, anti-Puritan rhetoric was able to kill a handful of birds with one stone: the fictional Puritan delineated the boundaries of non-conformity, and antiPuritan satire consolidated English Protestant orthodoxy.

The stigmatizing of Puritans as Jews, on stage and page, has led some critics to argue that Jewish stage characters, Shylock in particular, are better appreciated as thinly veiled representations of Puritans. 'Shylock may be a Jew,' Robin Headlam Wells has recently argued, 'but he has all the characteristics of the stereotypical Elizabethan puritan: he runs a "sober" house; he is self-righteous and thrifty; and he hates music, masquing and revelry. ${ }^{.107}$ In an earlier review of these sorts of claims, Walter Cohen concluded that 'the identification is unconvincing', not least 'because it is just as easy to transform [Shylock] into a Catholic' and, 'more generally, because he is too complex and contradictory to fit neatly the stereotype of Puritan thrift'. ${ }^{108}$

${ }^{106}$ Robert Davenport, A New Tricke to Cheat the Divell (London, 1639; STC 6315), F4v.

${ }^{107}$ Robin Headlam Wells, Shakespeare's Humanism (Cambridge: Cambridge University Press, 2005), p. 18. Others who have argued for a Puritan Shylock include Leeds Barroll, Artificial Persons (Columbia: University of South Carolina Press, 1974), p. 150; Hyam Maccoby, 'Shakespeare and Shylock', in Antisemitism and Modernity: Innovation and Continuity (New York: Routledge, 2006), pp. 97-107; Peter Milward, Shakespeare's Religious Background (Bloomington: Indiana University Press, 1973), pp. 158-61; Paul N. Siegel, 'Shylock and the Puritan Usurers', in Studies in Shakespeare, ed. by A. D. Matthews and Clark M. Emery (Coral Gables: University of Miami Press, 1953), pp. 129-38; and Paul N. Siegel, 'Shylock, the Elizabethan Puritan, and Our Own World', in Shakespeare in his Time and Ours (Notre Dame: University of Notre Dame Press, 1968), pp. 237-54.

${ }^{108}$ Walter Cohen, 'The Merchant of Venice and the Possibilities of Historical Criticism', ELH, 49 (1982), 765-89. On Shylock as a Catholic, see Lawrence Danson, The Harmonies of 'The Merchant of Venice' (New Haven: Yale University Press, 1978). 
Already stigmatized as Jews, the symbolic identification of the Puritans with the owl was sure to follow. In print, the anonymous author of a tract in the Martin Marprelate controversy promised to follow up with another pamphlet, entitled 'The Owles Almanack', in which he will 'sette down all the vpstart Religions in this Land', including the 'Anabaptists; the Family of Loue', and 'the diuersities of Puritans and Martinists, with a number more which you shall heare of when that Booke is Printed'. ${ }^{109}$ Not to be confused with the aforementioned Jacobean burlesque of the same title, this owlish almanac is presumably lost, was published under a different title, or the pseudonymous Pasquill simply failed to keep his promise and it never went to print.

The link between Puritans and owls was also made on the stage. In Twelfth Night, Sir Toby and his late-night revellers sing a catch knowing that it will 'rowze the night-Owle' (7558, II. 3. 57), that is, Malvolio. This description is fitting, since Malvolio is both 'a kinde of Puritane' (839, II. 3. 135) and a 'Weauer' (759, II. 3. 58). In early modern English usage, 'weaver' and 'Puritan' became synonymous, since the profession was in large part made up of Calvinist refugees from Flanders who brought the cloth-making industry with them. For example, a man in Puritan dress is described as a 'Geneva Weaver' in Jasper Mayne's comedy The Citye Match, ${ }^{110}$ and George Chapman's Monsieur D'Olive includes a sketch of a Puritan 'weauer' who has become 'purblind' from reading the small print of the Geneva Bible. ${ }^{111}$

Malvolio aside, another instance of a Puritan slighted as a weaver and an owl is found in Ben Jonson's Masque of Owles. Presented to Prince Charles at Kenilworth on 19 August 1624, the performance features the Ghost of Captain Cox mounted on his hobbyhorse as he introduces six 'Owles', the third of which is

\author{
A pure native Bird \\ This, and though his hue \\ Be not Coventrie-blue, \\ Yet he is undone \\ By the thred he has spunne, \\ For since the wise towne
}

${ }^{109}$ The Return of the Renowned Caualiero Pasquill of England (London, 1589; STC 19457), A $3^{v}$. Although often ascribed to Thomas Nashe, the authorship of the pamphlet (as is characteristic of tracts in the Marprelate controversy) remains uncertain. For an interesting discussion of anonymity and the authorship of the Marprelate tracts, see Marcy L. North, The Anonymous Renaissance: Cultures of Discretion in Tudor-Stuart England (Chicago: University of Chicago Press, 2003), chap. 5.

${ }^{110}$ Jasper Mayne, The Citye Match (Oxford, 1639; STC 17750), P1 ${ }^{\mathrm{r}}$.

${ }^{111}$ George Chapman, Monsievr D'Olive (London, 1606; STC 4983), D3r. 
Has let the sports downe

Of May-games, and Morris,

For which he right sorry is. ${ }^{12}$

This 'Owle third' is a Puritan weaver from Coventry - presumably 'his hue' is a more godly black than the blue thread he sells - whose zeal in tearing down maypoles and stamping out traditional holiday festivities has backfired and left him bankrupt. With no more 'dancings, and Wakes' at which to wear the 'Napkins, and poses' (p. 127) and other decorative attire for which his thread was once bought, the Puritan's religious fervour has brought about his financial demise. Having 'neither wit, nor lands' (p. 128) he has literally nothing else to do with his thread but hang himself.

Captain Cox's promise that the masque intended 'No ill meaning to the Catholique faith' (p. 126) perhaps should have also included a disclaimer for the local Puritans, since internal evidence suggests the part of the third owl was 'censured for its complaint against the Coventry City Fathers' and 'denied an audience' until it was printed. ${ }^{113}$ The printing of an alternate version of the third owl at the end of the Folio text, 'the third varied' (p. 128), suggests that the original was probably 'suppressed for the performance', with Jonson 'characteristically restoring the original text in the manuscript left behind him for the printer. ${ }^{114}$

\section{The Parliament of Owls}

As to be expected, the branding of radical sects - already conveniently lumped together as 'Puritans' - as owls reached its zenith during the period of religious and political unrest that ushered in the Civil War and Interregnum. In The Schismatick Stigmatized, Richard Carter dissects these various groups that sought

112 Jonson's Masque of Owles was first printed in the Second Folio (London, 1640; STC 14754), pp. 125-28, where it is erroneously dated 1626.

${ }^{113}$ Lambert, 'Expounding the Owl', p. 29. Lambert's article is the most comprehensive critical treatment of the Masque of Owles to date, and it offers a provocative reading of the performance as endorsing Jacobean policy at the same time as it 'subtly exposes an uncomfortable truth' (p. 29) about the policy in question. The third owl is mostly excluded from the discussion on the grounds that it was suppressed.

${ }^{114}$ Ben Jonson, Masque of Owles, ed. by C. H. Herford, Percy Simpson, and Evelyn Simpson (Oxford: Clarendon Press, 1925-52), X, 700. Stephen Orgel reaches the same conclusion in his edition of the Complete Masques, for the Yale Ben Jonson (New Haven: Yale University Press, 1969), p. 431. 
further reform of the Church - the 'rabble of Brain-sicks' and 'Eves-droppingnewes-carriers, Murmurers, Complainers, Railers, Reproachers, Revilers, Repining Reformers, Fault-finders, Quarrell-pickers, and Corner-creepers' - which he saw as 'enemies to Old Englands Peace. ${ }^{115}$ Gingerly noting their faults as part of his sectarian taxonomy, Carter describes those 'schismaticks' seeking 'parity and equality of Ecclesiasticall persions' as 'Owles, Crowes, and Mag-pyes' that 'would have our Church like Polyphemus, without eyes, and without order' (A3v).

Other satires were more precisely linked to immediate historical events. As part of a 'parliamentary visitation that had been authorized by the Long Parliament in 1647 to subjugate a university which, from 1642 to 1646 , had loyally served Charles I as the capital of royalist England', the Earl of Pembroke (Philip Herbert) was ordered by Parliament to take up his post as University Chancellor, arriving at Oxford in April 1648 to preside in convocation and to personally oversee the institution of reforms. ${ }^{116}$ As R. A. Beddard has noted, this newly imposed governance of the university consisted mostly of 'academics who had not only politically sided with the victorious rebel cause' but those that 'personally profited from the ejection of the defeated royalist dons, to whose posts they had been preferred wholesale'. ${ }^{117}$ In addition to bemoaning the loss of their stronghold and the purging of many of their number from academic positions, royalists responded by publishing a number of satires mocking Pembroke as too vulgar and ignorant for the post, and accusing his cohorts of hypocrisy, incompetence, and greed. One of these satires, An Owle at Athens (London, 1648; Wing W3098), lampooned the entrance of Pembroke into Oxford as 'the wise Lord, and's wiser Horse' (A2v) before proceeding to mock other parliamentary visitors and intruding academics. Proverbially it was folly to bring owls to Athens, since they were already there either literally (many were said to roost in the Parthenon) or figuratively (in much the same way that angels could refer to coinage that bore St Michael on its face, owls could refer to Athenian coins, since they bore the city's icon on their reverse). The pamphlet's title plays upon this double sense of folly, combining the owl's traditional association with foolishness and echoing the proverbial sense of pointlessness in sending an owl (Pembroke) and his Puritan 'Tribe of Hebrews' $\left(A 3^{r}\right)$ to Oxford, parliament's reclaimed Athens.

${ }^{115}$ Richard Carter, The Schismatick Stigmatized (London, 1641; Wing C664), title-page.

${ }^{116}$ R. A. Beddard, 'The Origin of Charles II's Visitation of the University of Oxford in 1660', Parliamentary History, 24 (2005), 261-94 (p. 261).

${ }^{117}$ Beddard, 'Origin of Charles II's Visitation', p. 261. 
Bringing owls to Athens was not the only owl proverb to be appropriated for partisan politics: the Dutch proverb, 'What use are candle and glasses, if the owl does not want to see', was 'frequently given expression in the pictorial arts, ${ }^{118}$ and English authors adapted it to satirize the various radical sects that sprung up during this period.

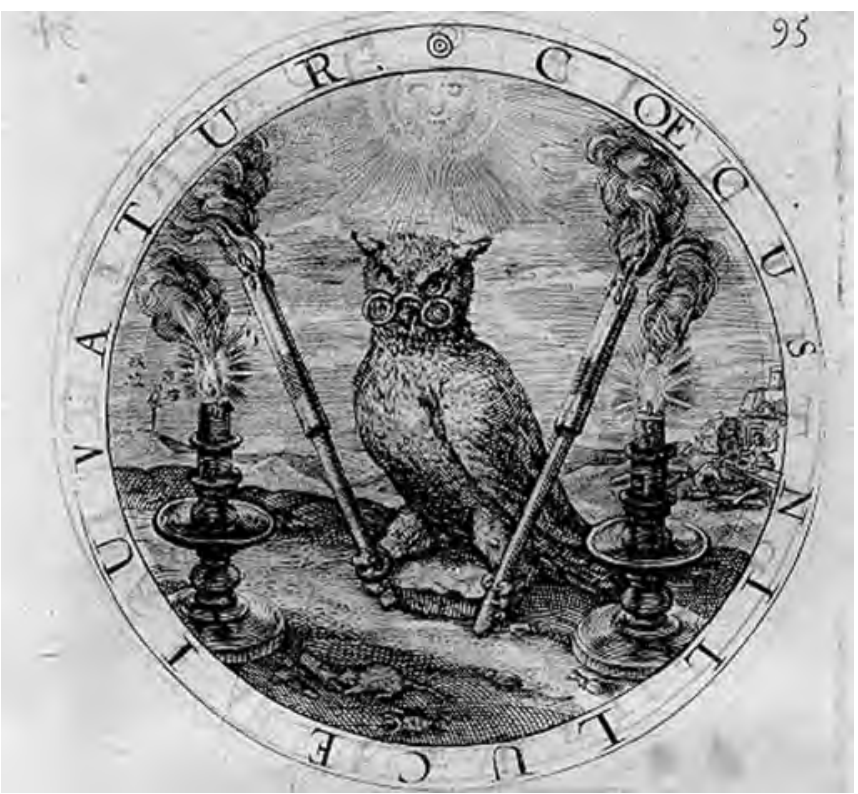
In his Collection of Figure 11. George Wither, A Collection of Emblemes (London, 1635), Emblemes, George Book 4, Illustr. XLV. Courtesy of Rare Books and Manuscripts, Special Wither employs the Collections Library, The Pennsylvania State University Libraries. motif in illustration

XLV of Book 4 (Figure 11), with the motto caecus nil luce juvatur ('Hee that is blind, will nothing see, | What light soe're about him bee'), singling out 'Heretickes' who 'cannot see the Rayes of Truth divine, | Though, brighter than the Day-light, shee doeth shine'. ${ }^{119}$

The motif appears in another broadside belonging to the period, Fanatick Madg (Figure 12), where an owl is perched on a book labelled 'The Association',

${ }^{118}$ Jane Russell Corbett, 'Convention and Change in Seventeenth-Century Depictions of Alchemists', in Art and Alchemy, ed. by Jacob Wamberg (Copenhagen: University of Copenhagen Press, 2006), pp. 249-72 (p. 251). The proverb was familiar throughout the Low Countries, as evidenced by a number of Dutch and German prints. Representative examples include emblems (Gabriel Rollenhagen, Nucleus Emblematum (Utrecht, 1613), emblem 95), broadsides (a print by Erhard Schön published in Nuremberg in 1540, contains a woodcut of the motif with the proverbial text, 'was hilfft mich sün liche oder prill | Weyl ich doch selbs nicht schen will'), and paintings (Jan Steen, The Drunken Couple, c. 1688-72, oil on panel, Amsterdam).

${ }^{119}$ George Wither, Collection of Emblemes (London, 1635), 2L $3^{\mathrm{r}}$. 


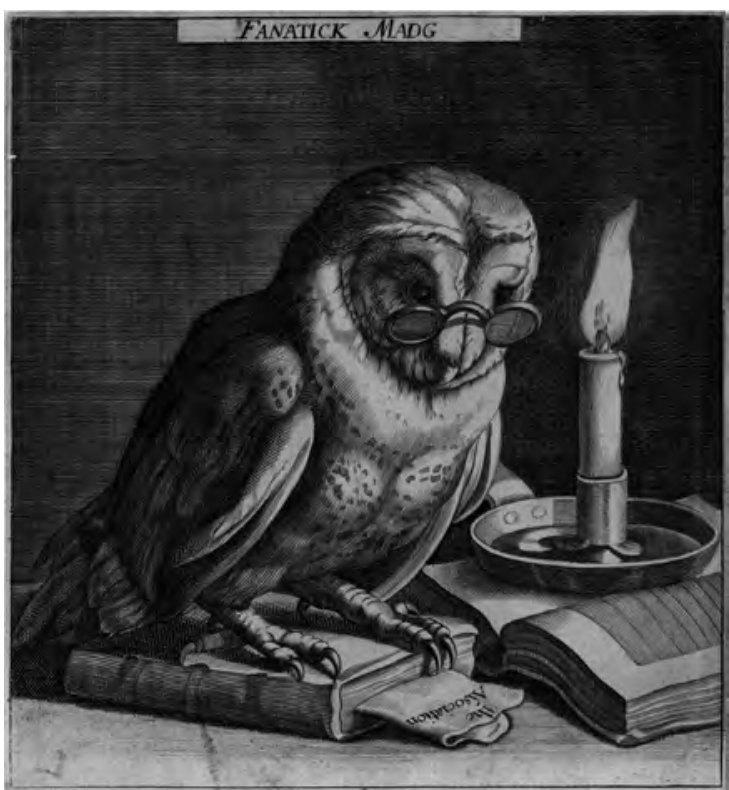

Figure 12. Fanatick Madg (BM Satires 228.I). Engraved broadside variously dated 1647-88. (C) Trustees of the British Museum, London. presumably alluding to the Eastern Association of parliamentary forces. ${ }^{120}$ The owl ('madg') is clearly associated with zealous ('fanatick') Puritans, as the accompanying verse makes clear: 'Lets pull [the] Popysh Bishops downe and Monarchy Expell | Then Liberty of Conscience Shall to euery one be free'. The verse ends by lampooning the revolutionary goal of the reformers: once the country has been purged of Papistry and Monarchy, the Puritan 'Tinckers \& Coblers all may preach' in their place.

The royalist campaign to associate the blindness and folly of Puritans and parliamentarians with the figure of the owl was completed in a series of prints satirizing Oliver Cromwell and, after his death, Richard Cromwell. The first of these is Danck-Predikatien (thanksgiving sermon), a Dutch broadside printed in 1651, which contains an engraving of the interior of a church, with Cromwell preaching to its congregation after the victorious Battle of Worcester. Drawing upon earlier Reformation satires, Cromwell is figured as a papal monster, complete with tiara and dragon's tail. By including scenes of theft (a boy picking pockets in the audience), plunder (an open window reveals the sale of goods plundered during the Battle), and heresy (an inset panel features the ghost of Bernhard Knipperdolling, leader of the Münster Anabaptists, rising from a grave to hand Cromwell a book), the print satirizes the 'purity' of the Puritan cause. Embodying all of the elements

${ }^{120}$ Fanatick Madg, British Museum, Satires 228. 1. The print is attributed to Jacob Collins, and although it is clearly based on a 1625 print by Cornelis Bloemaert, the precise date is uncertain. While it might have been published to satirize the Eastern Association during the 1640s, it may also have been printed in the 1680 s to tarnish the campaign to expel James II with the memory (and ultimately, the failure) of the Civil War. 
of the satire - heresy, greed, and monstrosity is the figure of the owl, which hovers above Cromwell at the pulpit (Figure 13).

A Dutch print satirizing Cromwell's dismissal of the Rump Parliament in 1653, Dit Hoys is te Hver (This House is to Let), features Cromwell's famous remark ('Be gone you rogues | You haue Sate long enough') and the ejection of Members from the House, including a group of four led out by an owl wearing

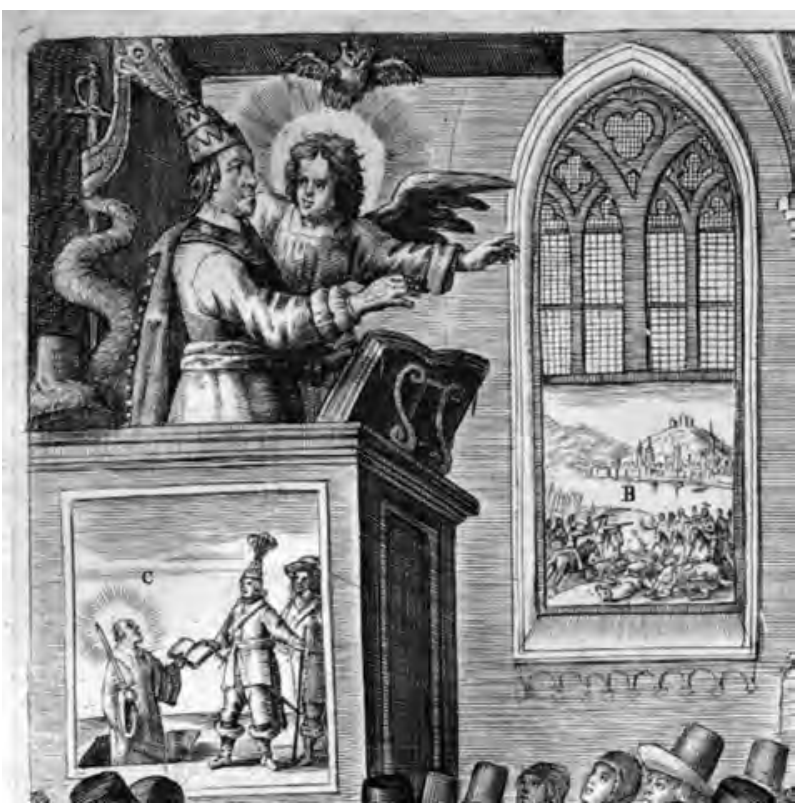

Figure 13. Detail. Danck-Predikatien (BM Satires 818). Engraved broadside dated 1651. (C) Trustees of the British Museum. spectacles and a collar in which a candle is attached (Figure 14). To ensure that the viewer correctly identifies the bird - and thereby grasps the double sense of parliament as both the institution being dissolved and the collective noun for a group of owls - the label 'This is an Oule' is written underneath.

Another Dutch print of the same year, Olivier Cromwel, Proteckteur GeeWeest, is a caricature of its subject (Figure 15). As part of her study of representations of Cromwell, Laura Lunger Knoppers describes the image as follows:

Cromwell wears plain civilian dress, with a fur-lined coat, simple collar and cuffs, and a beaver hat. But now a raven perches atop Cromwell's broad-brimmed hat, to which stag's horns and a feather have also been added. Spectacles are perched on his oversized nose, and a smoking pipe is in his mouth. To further ridicule the figure of the Protector, an owl, who likewise sports a horned cap and spectacles, perches on Cromwell's right shoulder. ${ }^{121}$

Useful as a summary, Knoppers's analysis of the image fails to address its iconographic elements, all of which point to the identification of Cromwell with the

${ }^{121}$ Laura Lunger Knoppers, Constructing Cromwell: Ceremony, Portrait, and Print, 1645-1661 (Cambridge: Cambridge University Press, 2000), p. 88. 


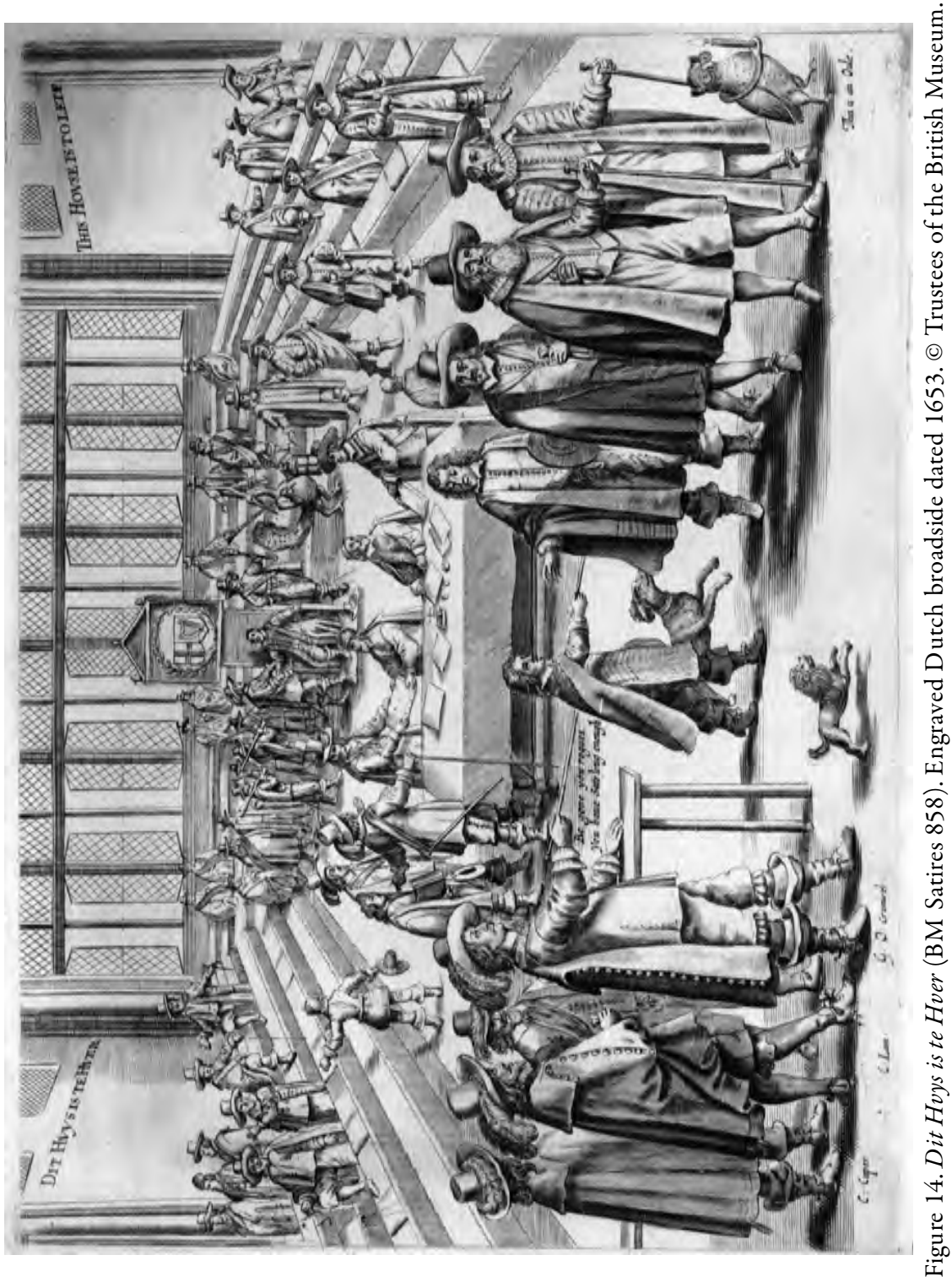




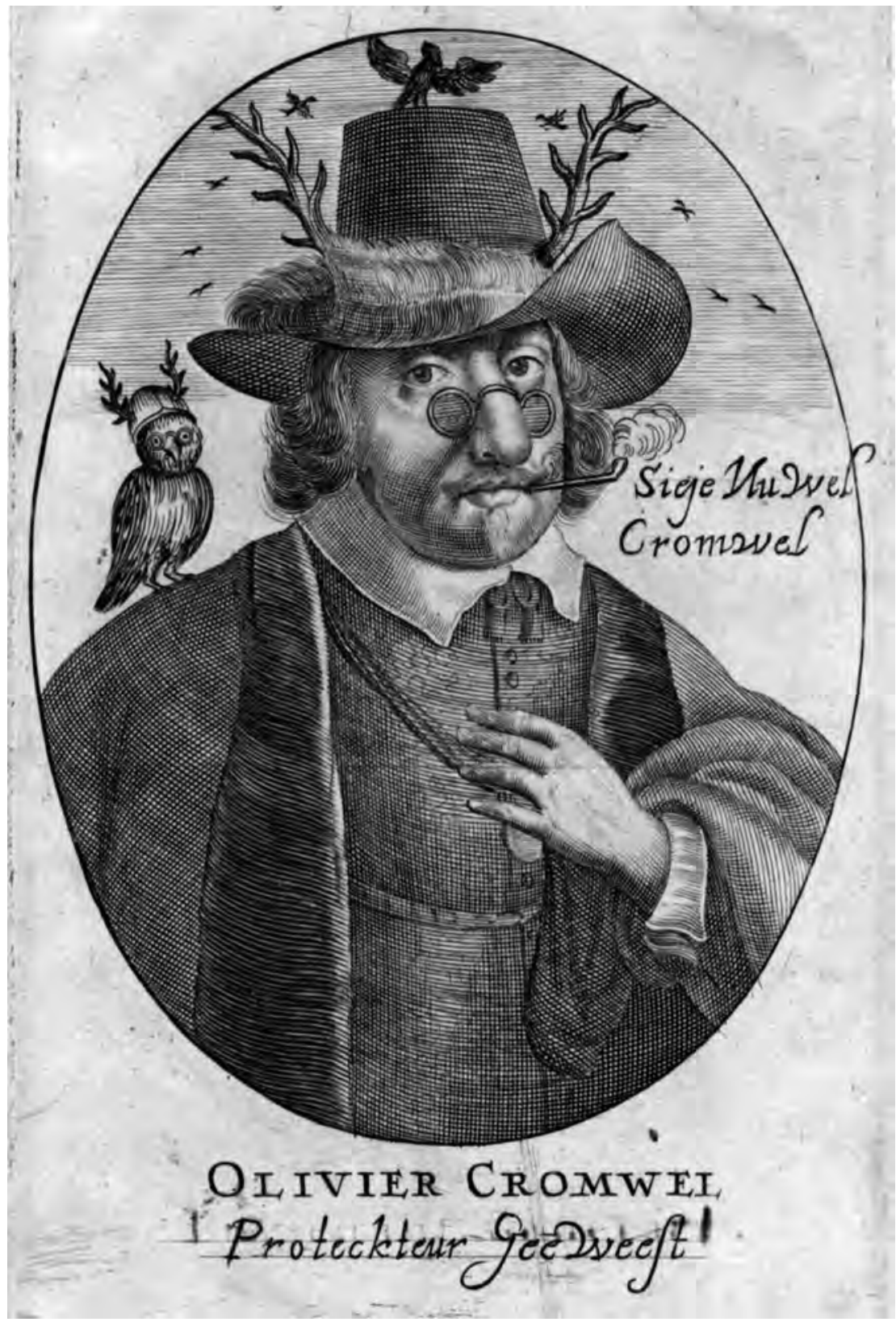

Figure 15. Olivier Cromwel, Proteckteur GeeWeest (BM Satires 866).

Engraved Dutch broadside dated 1653. (C) Trustees of the British Museum. 
figure of Nobody, the epitome of foolishness. 'Spectacles as aids to failing sight had been popularly distrusted since their invention', writes Gerta Calmann, noting that they 'were often used to ridicule their wearers' since they 'signified pretensions to learnedness, or specious truth, and belonged clearly to the fool's outfit'. Feathered caps often suggest foolish ostentation, but what about a whole bird? The bird on top of Cromwell's hat, identified by Knoppers as a raven, is for Calmann 'an attribute that is iconographically extremely rare', and one that is almost always used in connection with the Nobody figure. ${ }^{122}$ While the horns on Cromwell's hat clearly suggest the sexual folly of the cuckold, ${ }^{123}$ and perhaps foolish ostentation, they may also be a corrupted reference to the traditional winged headdress of the Nobody. The pipe and feather similarly insinuate garishness and presumption. The owl on his shoulder, a symbol of blindness and folly, and, by this time, a well-worn emblem of the Puritan, needs no further explanation.

When Oliver Cromwell died on 3 September 1658, he passed on more than just the title of Lord Protector to his son: Richard Cromwell would inherit the same symbolic association with the owl that had plagued his father and his cause. In Lord Richard Cromwel, a Dutch broadside of 1658-59, Richard is caricatured as a cooper hammering away at a barrel with a mallet, from which a parliament of owls wearing spectacles and clutching candles escapes, each crying 'King!' as it does so (Figure 16). An inset panel on the left depicts a scene from Aesop's fable of The Frogs Desiring a King, with a stork devouring frogs as Jove looks on, while another panel on the right displays a state proclamation delivered to a courtyard full of onlookers (presumably announcing Richard as his father's successor). As Annabel Patterson has noted, Aesop's 'frog fable took on a new lease of life' during the Civil War, Interregnum, and Restoration periods, where it participated in the republican debate in print and pulpit. ${ }^{124}$ The present broadside presents the fable as an analogy: just as the frogs were wrong to question divine authority and were punished accordingly, so too has the parliament of owls in rejecting the monarchy ended up with Richard Cromwell.

${ }^{122}$ Calmann, 'The Picture of Nobody', p. 66.

${ }^{123}$ As Jason McElligott has shown, 'Cromwell was invariably portrayed as both a lecher and a cuckold' in Royalist propaganda: 'The Politics of Sexual Libel: Royalist Propaganda in the 1640s', Huntington Library Quarterly, 67 (2004), 75-99 (p. 83). I am indebted to David Scott Kastan for pointing this reference out to me.

${ }^{124}$ Annabel Patterson, Fables of Power: Aesopian Writing and Political History (Durham: Duke University Press, 1991), p. 94. In chap. 3, Patterson traces how various editions, translations, and commentaries of Aesop's fable were intimately tied to partisan politics. 


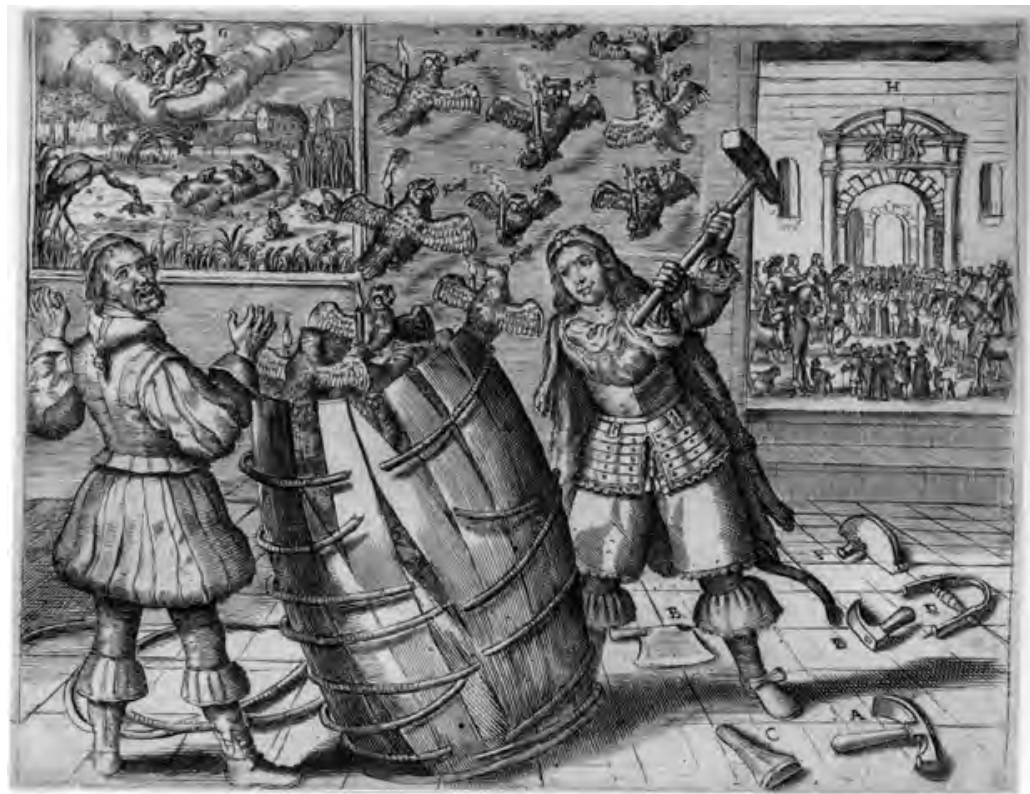

Figure 16. Lord Richard Cromwel (BM Satires 921). Engraved Dutch broadside dated 1658-59. (C) Trustees of the British Museum.

Although printed in London in 1659 , the final print in this series is clearly informed by earlier Dutch satires of Oliver Cromwell. The broadside, entitled His Highnesse Hoo. Hoo. Hoo., caricatures Richard Cromwell as a giant owl (with human legs) astride a horse, with a plumed hat on his head and a pipe in his beak, as he is being mobbed by a group of smaller birds (Figure 17). The woodcut of Cromwell as the 'Protector of Lubberland, and chief Captain of the night Guards' is accompanied by the following verse:

I am resolved to ride in State,

Not caring what the small Birds prate.

I'le keep my Seat without controul,

If once I flinch they'l call me Owle.

Like his father in the earlier Dutch print, Richard is mocked for his foolishness; his ridiculously gaudy hat, notably bigger than his head, and his outrageously long pipe speak for themselves. The print also highlights Richard's presumption: in the verse, by obstinately ignoring the 'small Birds prate' (possibly the disaffected Army) and refusing to abandon his 'Seat without controul', and in the woodcut, by donning military attire, riding a cavalry horse, and carrying an officer's sword and powder horn (Richard's lack of military experience was a frequent subject of criticism). 


\section{Conclu-hoo-hoo-sion}

The owl's association with Athena/ Minerva and wisdom was given renewed life by Renaissance humanists who sought to recover and reinvigorate all aspects of their classical heritage. While this tradition continued (and survives to this day), other symbolic associations flourished. 'The power and richness of the owl as a pictorial motif, writes Mariko Miyazaki, 'lies in its versatility and long tradition of negative traits, such as blindness and uncleanness', ${ }^{125}$ traits that were readily adaptable for the stigmatization of minorities and unorthodox groups. Thus, in medieval England the owl served as the embodiment of Jewish blindness, folly, and filthiness. As a nocturnal predator, the owl also symbolically reflected projected fears and anxieties of Jewish crimes against

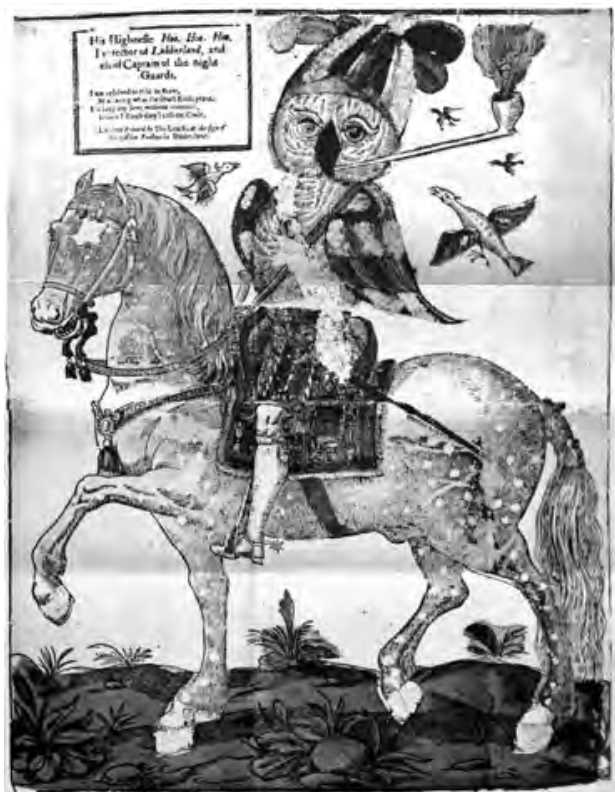

Figure 17. His Highnesse Hoo. Hoo. Hoo. (London, 1659). Clarke Print Collection, Worcester College, Oxford. Reproduced as the frontispiece of The Clarke Papers, vol. III, ed. by C. H. Firth (New York: Longmans, 1899), where the present copy was sourced.

Christians, especially Christian children, under cover of darkness. In the same way that the sun took away the owl's ability to hunt effectively, so too did the light of the Gospel reveal Jewish error and infidelity, the light of day also diminishing the threat of the owl, and the Jews, making them easier to identify, demystify, and contain. From its nest in the textual and visual narratives of the poems, bestiaries, and ecclesiastical architecture of the Middle Ages, the owl survived as an antisemitic emblem in England long after the Jews had been expelled from its shores - evidenced by the many references to 'owle-eyed' Jews and their inability to acknowledge the Light of Christ and his Gospel.

The various Reformations irreversibly changed the political and religious landscape of Europe, and as with other powerful symbols, the antisemitic owl was adapted to suit. As charges of judaizing were hurled between Catholics and 
Protestants alike, the owl again emerged as an emblem of Jewish perversity and monstrosity. Fuelled by this sectarian rhetoric and Robert Persons's unfortunate choice of John Howlet as a pseudonym, the owl became closely aligned with the Jesuits and their Catholic mission to restore England to the old faith. Leaving their Romish nest, Jesuit conspirators preyed on good Protestants as they flew through the country under cover of darkness and disguise, and London playwrights were quick to seize upon their popular identification with the owl.

In the seventeenth century, the Puritan factions at Parliament gained more power and presented a new threat, while at the same time lending themselves nicely to caricature and satire. As with Catholics, Puritans were charged with judaizing tendencies, and the connection with the owl was made. In addition to symbolizing the Puritans' reversion to Judaism, the owl was adapted as an anti-Puritan image because it too was a 'roundhead', a bird unique in having both its eyes at the front of its (round) face, and both congregated in parliaments. In so doing, the author of My Bird is a Round-head drew on more than a quirk of biology and a fortuitous choice of collective noun, but on a much longer tradition of stigmatizing unorthodox religious groups, one that had persisted since the thirteenth century. 